\title{
Corporate Venture Capital Portfolios and Firm Innovation
}

\author{
Anu Wadhwa* \\ College of Management of Technology \\ Ecole Polytechnique Fédérale de Lausanne \\ Lausanne, Switzerland 1015 \\ Phone : +41216930030 \\ Email : anu.wadhwa@epfl.ch
}

\author{
Corey Phelps \\ Desautels Faculty of Management \\ McGill University \\ Montreal, Canada \\ Phone: +15143984007 \\ Email: corey.phelps@mcgill.ca
}

Suresh Kotha

Foster School of Business

University of Washington

Seattle, WA 98185

USA

Phone: +1-206-543-4466

Email: skotha@u.washington.edu

This Version : April 2015

Forthcoming in Journal of Business Venturing

We would like to thank Gautam Ahuja, Kevin Steensma, and Chris Tucci, for their helpful comments and suggestions on earlier drafts of this paper. We are also grateful to Simon Rodan for his assistance with the data and variable computations. Feedback from participants at the SMS and Babson annual conferences is also highly appreciated. 


\title{
Corporate Venture Capital Portfolios and Firm Innovation
}

\begin{abstract}
This study examines the conditions under which portfolios of corporate venture capital (CVC) relationships influence corporate investor innovation performance. We investigate this question using longitudinal data on CVC investment portfolios of 40 telecommunications equipment manufacturers. We find an inverted Ushaped effect of portfolio diversity on corporate investor innovation performance. We also find that the effect of diversity depends on the depth of knowledge resources available in the portfolio. These results contribute to the interorganizational learning, corporate venture capital and open innovation literatures by showing how the depth and breadth of knowledge resources available in a portfolio of external partnerships with young ventures interact to influence firm innovation.
\end{abstract}




\section{Executive Summary}

Because innovation is critical to organizational performance and longevity, firms often form collaborative knowledge-sharing relationships with one another to improve their innovation performance. A growing stream of research has examined how characteristics of a firm's portfolio of such relationships influence its learning and innovation. Although recent studies highlight the importance of portfolio diversity - the extent to which a firm's partners represent diverse sources of knowledge, evidence on whether portfolio diversity is beneficial or harmful for firm innovation is mixed and inconclusive. Accordingly, several scholars have adopted a contingency perspective by examining how the influence of portfolio diversity depends on other factors, such as features of a firm's competitive environment. A potentially important contingency that prior research has overlooked is how the depth of knowledge available to a firm in its portfolio of partnerships influences the relationship between portfolio diversity and innovation.

In this study, we address this gap by drawing on the recombinatory search literature and examining whether and how the influence of portfolio diversity on firm innovation depends on the depth of knowledge resources that partners possess or have access to. Our baseline hypothesis is that portfolio diversity has an inverted U-shaped effect on firm innovation: initial increases in diversity are beneficial for innovation, but ultimately turn negative beyond moderate levels. We also posit that the depth of knowledge available to a firm in its portfolio of partnerships, as reflected by the technological and social capital of its partners, will positively moderate the impact of portfolio diversity on innovative performance.

To test our model, we use longitudinal data on the corporate venture capital (CVC) investment portfolios of 40 global telecommunication equipment manufacturers. Corporate venture capital - direct minority equity investments made by established firms in privately held entrepreneurial ventures - is an increasingly important and prevalent means by which firms pursue interorganizational learning. Our results are consistent with our theoretical expectations. We find that corporate investors maximize their innovation performance when they invest in moderately diverse portfolios of startups. More importantly, our results show the relationship between portfolio diversity and firm innovation is enhanced as the partners' stock of patented technologies and alliance partners increase.

Our study makes several contributions. First, we contribute to research on portfolios of interorganizational relationships and firm innovation by using a network based measure of portfolio diversity 
that captures both the differences among a focal firm's partners and the differences between it and its partners. Our results show that increases in both of these aspects of portfolio diversity impact firm innovation. Our results also help us understand how the depth of partners' technological knowledge and the extent of their social capital can help a firm reduce the costs and enhance the benefits of portfolio diversity for innovation. Third, we contribute to research on corporate entrepreneurship by providing empirical evidence that portfolios of CVC relationships provide strategic benefits to a corporate investor by improving its innovation. Finally, we contribute to open innovation research by identifying when and how portfolios of corporate venture capital relationships, an important tool of open innovation, influence investor innovation.

\section{Introduction}

The creation and commercial exploitation of technological knowledge (i.e., innovation), often in the form of new products and services, is central to the sustained economic performance of firms (Roberts, 1999) and their survival (Cefis and Marsili, 2005). To improve innovation performance, firms often form collaborative, interorganizational knowledge sharing relationships (Hagedoorn and Narula, 1996). As these arrangements have grown in popularity across industries and throughout the world (Hagedoorn, 2002), research exploring their influence on organizational learning and innovation has also blossomed (Ahuja et al., 2008). Although most studies have focused on characteristics of individual collaborative relationships (e.g., Sampson, 2007), research has recently begun to examine characteristics of an organization's collection of interorganizational relationships and the influence these portfolios have on learning, innovation and other aspects of organizational performance (Hoffmann, 2007; Lavie, 2007; Ozcan and Eisenhardt, 2009; Sarkar et al., 2009; Wassmer, 2010). Portfolios of interfirm relationships matter because ties within a portfolio can complement or conflict with one another, thereby influencing whether the value organizations derive from their portfolios is more or less than the sum of the values of the individual ties (Vassolo et al., 2004; Wassmer, 2010). Recent research has explored how the diversity of ties within a portfolio influences the nature and degree of interdependencies among them and their contribution to portfolio value (Lin and Lee, 2011; Yang et al., 2013). In particular, many studies have examined the influence of portfolio diversity on firm innovation (Phelps et al., 2012). Despite this growing interest, research investigating how and when portfolio diversity influences firm innovation is limited in at least one important respect.

Prior research has yielded conflicting and thus inconclusive results regarding the influence of 
partnership portfolio diversity on firm innovation performance (Lee et al., 2014; Wuyts and Dutta, 2012). While some studies find portfolio diversity has a positive effect on firm innovation (de Leeuw et al., 2014; Phelps, 2010; Srivastava and Gnyawali, 2011; Wuyts et al., 2004), others have found support for a nonlinear, inverted-U shaped effect (de Leeuw et al., 2014; Duysters and Lokshin, 2011; Luo and Deng, 2009; Van de Vrande, 2013; Vasudeva and Anand, 2011) as well as a U-shaped effect (Wuyts and Dutta, 2012). Thus, it is unclear when portfolio diversity is beneficial or detrimental for firm innovation.

Rather than look for a generalizable main effect, an alternative approach to understanding the influence of portfolio diversity on firm innovation would be to adopt a contingency perspective. Indeed, examining moderators is a principle strategy of unpacking and understanding conflicting main effect results. Several studies that have done so have found that not all firms benefit equally from the same level of diversity in their portfolio of interfirm relationships. This research has examined the moderating influence of focal firm characteristics (Cui and O’Connor, 2012; Koka and Prescott, 2008; Luo and Deng, 2009; Srivastava and Gnyawali, 2011; Wuyts and Dutta, 2012; Wuyts et al., 2004), the competitive environment (Cui and O’Connor, 2012; Koka and Prescott, 2008; Luo and Deng, 2009), and the technological distance between a focal firm and its partners (Vasudeva and Anand, 2011). This research has not, however, explored whether the impact of portfolio diversity on firm innovation depends on portfolio characteristics, such as the depth of knowledge that portfolio partners possess or have access to. This is surprising because work on innovation search suggests the depth of knowledge to which a firm has access in its search space conditions the costs and benefits it experiences in searching diverse knowledge sources (Katila and Ahuja, 2002).

We address this limitation by examining the conditions under which the diversity of knowledge resources available to a firm in its portfolio of collaborative interorganizational relationships influences its innovation performance. First, we predict and test a baseline hypothesis that the diversity of a firm's portfolio of partners has an inverted U-shaped effect on its innovation performance. We argue the contribution of a partnership to a firm's innovation performance cannot be assessed independent of the diversity in the firm's portfolio of partnerships because diversity will influence the costs and benefits of each relationship. We identify how portfolio diversity generates both complementary and substitutive effects across relationships within a portfolio and when these interactions yield super- or sub-additive effects at the portfolio level for a firm's innovation performance. Second, we posit that two characteristics of a firm's 
portfolio of partners will moderate the impact of portfolio diversity on its innovative performance: (1) technological capital (i.e., the stock of technological knowledge possessed by the partners), and (2) social capital (i.e., the collaborative, interorganizational knowledge-sharing relationships in which the partners participate). Both the technological knowledge stock and social capital of a firm's portfolio of partners reflect knowledge resources that the portfolio partners have access to (Ahuja, 2000; Phelps et al., 2012).

We test our hypotheses using longitudinal data on the corporate venture capital (CVC) portfolios of 40 telecommunications equipment manufacturers during the period 1989-2000. Corporate venture capital direct minority equity investments made by established firms in privately held entrepreneurial ventures - is an increasingly important and prevalent means by which firms pursue interorganizational learning (Dushnitsky and Lenox, 2006). After controlling for fixed firm and time period effects and alternative knowledge sources including alliances and acquisitions, we find that firms maximize their innovation performance when they invest in moderately diverse portfolios of startups, and that this relationship is enhanced as the technological and social capital of the ventures in the portfolio increase. This study contributes to research on interorganizational learning and firm innovation by showing how the depth of knowledge available in a portfolio of partners, either from the knowledge partners already possess or have access to as result of their other interfirm partnerships, moderates the influence of portfolio diversity on firm innovation. Prior research has not examined either of these contingent effects. Moreover, we contribute to research on corporate venture capital and open innovation by identifying the conditions under which portfolios of CVC relationships, an important tool of open innovation, influence investor innovation.

\section{Empirical Context}

A particularly appropriate setting in which to explore our question are corporate venture capital (CVC) portfolios - the collection of direct minority equity investments established firms make and maintain in privately-held entrepreneurial ventures (Dushnitsky, 2006). Established companies across many industries often maintain CVC portfolios as a result of investing in multiple startups (Basu et al., 2011). This setting is an appropriate context to explore our research question for several reasons. First, CVC relationships represent an important source of knowledge for CVC investors by establishing boundary spanning ties with new ventures, which often pursue novel technologies (Dushnitsky and Lenox, 2005). Firms most often undertake CVC investing to learn about novel technologies (Dushnitsky, 2006). CVC ties can influence an 
investing firm's innovation performance by increasing the amount and variety of knowledge flows available to an investing firm's innovation efforts (Dushnitsky and Lenox, 2005; Wadhwa and Kotha, 2006). These flows are promoted by the investor's evaluation and monitoring of, and collaboration with, its portfolio of ventures (Dushnitsky and Lenox, 2005). Second, this context lends itself to an investigation of how portfolio diversity influences interdependencies across partners within a portfolio. Prior research suggests that portfolios of minority equity relationships exhibit interdependencies that influence their overall value (Lin and Lee, 2011; Vassolo et al., 2004). Research also shows that CVC investors exhibit substantial variation in the diversity of their portfolios (Basu et al., 2011; Lin and Lee, 2011), which will help in estimating the effect of diversity on investor innovation. Third, this setting has methodological advantages. Because a CVC investment provides an endorsement effect that sends a positive signal of a startup's quality to current and potential stakeholders (Stuart et al., 1999), entrepreneurs have strong incentives to publicly disclose such investments. Moreover, the vast majority of CVC investments are syndicated with independent venture capitalists (Dushnitsky, 2006 ) and these investors systematically self-report their investments to data collection organizations and trade associations. Consequently, information about a corporate investor's entire portfolio of CVC relationships is more likely to be available than similar information about a firm's alliance portfolio. Additionally, CVC investments also represent an important and distinct class of interfirm relationships (Dushnitsky and Lavie, 2010) that allow us to examine the effect of portfolio diversity based on portfolio partner attributes by holding the type of relationship and type of partner constant.

Finally, this setting is important in its own right. CVC ties are typically formed by investors to access and learn about new technologies (Dushnitsky, 2006). Yet, existing CVC research provides little insight into the conditions under which investors actually derive learning benefits from such relationships (Dushnitsky, 2006). Investigating how a firm's CVC portfolio impacts its innovation performance will help fill this gap. Although recent evidence shows that interdependencies among ventures within CVC portfolios influence growth and value creation for the corporate investor (Lin and Lee, 2011; Yang et al., 2013), CVC research has largely overlooked whether and when the diversity of resources possessed by an investor's portfolio of venture partners and the conflicts and complementarities present among such ties also have an impact on the investor's innovation. Additionally, prior CVC research has not examined whether the impact of a firm's portfolio of CVC ties on its innovation performance depends on the depth of technological knowledge 
possessed or accessible by its portfolio ventures. This omission is noteworthy because research has shown that the depth of knowledge to which a firm has access in its innovation search moderates the costs and benefits it experiences from searching diverse sources of knowledge (Katila and Ahuja, 2002). In sum, prior research provides little insight into the conditions under which portfolios of CVC investments influence a corporate investor's innovation performance.

\section{Theory and hypotheses}

Innovation is a problem-solving process in which solutions to economically valuable problems are discovered via a costly process of search (Dosi, 1988). Search processes leading to the creation of new knowledge, often embodied in patents and new products, involve the novel recombination of existing knowledge elements (Fleming, 2001), or the reconfiguration of how knowledge elements are linked (Henderson and Clark, 1990). While firms typically pursue recombinatory search by drawing on local knowledge found within their boundaries ((Katila, 2000; Katila and Ahuja, 2002), they may also pursue recombinations of distant knowledge residing in other firms (Nahapiet and Ghoshal, 1998). Because knowledge is widely and heterogeneously distributed across firms (von Hayek, 1945), knowledge exchange is often necessary for recombination (Nahapiet and Ghoshal, 1998). Interfirm ties, a key mechanism for search as well as a medium of knowledge transfer (Ingram, 2002), allow firms to access and exchange familiar and unfamiliar knowledge. Firms that are able to search for and identify potentially useful knowledge, conceive of how it can be fruitfully recombined, and effectively access and assimilate this knowledge increase their chances of innovation (Galunic and Rodan, 1998). Interfirm ties are thus important for recombination. Moreover, such ties constitute a form of social capital because they are formalized social relationships between collectives through which instrumentally valuable resources are accessible (Nahapiet and Ghoshal, 1998).

CVC investments are formalized interfirm relationships that can provide partners with access to each other's resources (Dushnitsky and Shaver, 2009). Such access helps increase the amount and variety of knowledge flows available to a firm's recombination efforts, potentially resulting in increased innovation. Many aspects of a CVC relationship facilitate access to a startup's knowledge. First, before investing, corporate investors typically conduct due diligence on various aspects of a venture including its management team, business plan, financials, target markets, products, and technology (Dushnitsky, 2006). Often, personnel from the investor's R\&D group and a relevant business unit are involved in assessing the 
technology and products (Dushnitsky, 2006), which provide useful learning opportunities and help establish relationships with venture personnel for an on-going information exchange (Basu et al., 2011). Second, upon investment, corporate investors generally obtain either a board seat or board-observer rights with experienced business unit managers or R\&D personnel often filling such board roles. These individuals act as conduits through which useful information about the venture's strategic activities and technology is channeled back to the investor organization. These individuals also facilitate the development of mutually beneficial learning relationships between venture personnel and the investor (Basu et al., 2011). Intensive social interaction between an investor and portfolio firm increases their interorganizational learning (Maula et al., 2009). Finally, corporate investors typically undertake frequent and systematic meetings with portfolio firms in order to evaluate technology development and other performance indicators. In sum, research shows that CVC investing can enhance a corporate investor's innovativeness (Dushnitsky and Lenox, 2005; Keil et al., 2008; Wadhwa and Kotha, 2006). A firm that invests in multiple startups over time develops a portfolio of ventures and gains access to a search space comprised of their knowledge.

We argue that the nature of knowledge embedded in an investor's portfolio of startups has implications for its recombination by the investor and thus its innovation performance. The recombinatory search literature has emphasized the importance of two dimensions of a search space for successful recombinations - breadth and depth (Fleming, 2001; Katila and Ahuja, 2002; Schilling and Green, 2011). While breadth (or "scope") refers to the diversity of different topical domains of knowledge an actor searches, depth refers to the accumulated stock of knowledge in a particular domain accessible in an actor's search efforts (Katila and Ahuja, 2002; Laursen and Salter, 2006). We consider the influence of both the diversity and depth of knowledge accessible by a corporate investor in its portfolio of CVC relationships on its innovation performance. In examining the influence of knowledge depth, we build on prior research and focus on both the stocks of knowledge partners possess and the depth of knowledge spillovers to which they have access as a result of their own interfirm ties (Ahuja, 2000; Phelps et al., 2012).

Increasing compositional diversity of a firm's partners provides it with greater access to diverse knowledge beyond its boundaries (Baum et al., 2000). As such, increasing portfolio diversity presents both increasing benefits and challenges to firm innovation (Phelps et al., 2012). Extant research investigating the influence of portfolio diversity on firm innovation performance provides conflicting and inconsistent 
results. Specifying the conditions under which the benefits of portfolio diversity for firm innovation outweigh the costs and vice versa may help untangle these conflicting results. Consequently, the examination of potential moderators is warranted. We sought to identify potential moderators of the influence of increasing search scope by examining the innovation search literature (Ahuja et al., 2008; Laursen, 2012). This literature suggests that the benefits and costs of searching increasingly diverse sources of knowledge are conditioned by the depth of knowledge in the search space (Katila and Ahuja, 2002). Research shows that the depth of partners' technological knowledge stocks increases interfirm learning and firm innovation performance by increasing the volume and richness of knowledge available for recombination (Baum et al., 2000; Stuart, 2000). In addition, interorganizational network research shows that a firm's innovation performance increases as the volume of knowledge spillovers its partners have access to as a result of their own interfirm ties increases (Ahuja, 2000). A focal firm benefits not only from the depth of its partners' knowledge stocks but also from the depth of external knowledge to which the portfolio firms have access. Increasing search breadth facilitates the identification of promising knowledge elements for recombination, while increasing depth allows the searcher to investigate more deeply and better understand the different knowledge domains, thereby increasing the ability of the searcher to integrate and combine the knowledge with its own (Gavetti and Levinthal, 2000; Katila and Ahuja, 2002).

We first develop a baseline hypothesis relating the diversity of portfolio firms to the innovation performance of CVC investors. Next, we argue that this relationship is conditioned by two important characteristics of the ventures in a portfolio - the depth of the knowledge base of the ventures and the knowledge to which the ventures have access through their other interfirm partnerships.

\subsection{Portfolio diversity}

Diversity refers to the extent to which a system consists of uniquely different elements, the frequency distribution of these elements, and the degree of difference among them (Stirling, 2007). Accordingly, following other studies (Phelps, 2010; Rodan and Galunic, 2004), we conceptualize a focal investor and its portfolio firms as a system and define portfolio diversity as the extent to which the resources and capabilities, including technological knowledge, of startups in a portfolio differ from each other and from those of the investor. Portfolio diversity impacts innovation performance in four ways.

First, portfolio diversity affects the relative novelty of knowledge available in a portfolio. An increase 
in portfolio diversity increases the extent to which a CVC investor's startups are dissimilar from it and from each other, increasing the investor's access to relatively novel knowledge that is necessary for innovation (Greve, 2007). Access to diverse, non-redundant knowledge increases the number and variety of possible combinations, thereby increasing the potential for novel solutions (Fleming, 2001), challenges existing cognitive structures and beliefs about cause-effect relationships, which can promote new associations and lead to novel insights and solutions (Simonton, 1999), allowing firms to develop multiple conceptualizations of problems and solutions and to potentially apply solutions from one domain to problems in another (Hargadon and Sutton, 1997). It can also stimulate intensive experimentation with new combinations, leading to highly novel innovations (Ahuja and Lampert, 2001).

Second, portfolio diversity affects partners' willingness to share knowledge and reduces partner protectiveness. When firms develop similar domains of expertise their knowledge bases may become substitutable (Stuart and Podolny, 1996). When a CVC investor's portfolio consists of startups with similar (i.e., non-diverse) and thus substitutable knowledge stocks, competitive concerns among investors and startups can lead to increased incentives to protect and/or distort their knowledge (Dushnitsky and Shaver, 2009). Thus, decreasing portfolio diversity leads to a negative interaction across ties in the portfolio by reducing the amount and fidelity of knowledge flows. In contrast, an increase in portfolio diversity will have a complementary effect by increasing the incentives for partners to share knowledge because they will be less concerned that knowledge will leak to other substitutive startups in the portfolio via a common investor (Khanna et al., 1998) or that the investor is pursuing substitutive R\&D (Dushnitsky and Shaver, 2009).

Third, portfolio diversity also influences a corporate investor's relative absorptive capacity. A firm must expend greater effort and resources to understand and integrate dissimilar knowledge (Cohen and Levinthal, 1990). Cognitive capacity constraints and limited experience with diverse knowledge domains reduces a firms' ability to attend to and comprehend the interactions among increasingly dissimilar knowledge components (Fleming and Sorenson, 2001). Moreover, integrating novel knowledge from dissimilar sources often requires changing existing patterns of communication, which is difficult for established organizations (Kogut and Zander, 1992). As the dissimilarity between partners increases, their ability to recognize, assimilate, and apply each other's knowledge declines (Lubatkin et al., 2001), thus increasing the costs of recombinatory innovation (Weitzman, 1998). These costs can be mitigated to the 
extent that a corporate investor has invested in dissimilar startups which are themselves similar to each other because relationship-specific investments in cooperating with, and learning from, one portfolio venture can be efficiently leveraged in learning from other portfolio ventures (Vassolo et al., 2004). Thus, sunk cost investments in improving an investor's relative absorptive capacity with dissimilar startups are complementary (i.e., super-additive) across partnerships when startups pursue the same industries. In contrast, the costs of innovation for a CVC investor due to diminished absorptive capacity will be greatest when its portfolio startups differ greatly from both the investor and from each other because the investor incurs the cost of absorbing highly diverse knowledge without any compensatory benefit of being able to exploit learning from startup-specific investments across partnerships.

Finally, portfolio diversity affects the resource constraints an investor faces in managing its relationships. Interdependencies in a portfolio arise as a result of capacity constraints in the resources a firm contributes to its portfolio (Anand et al., 2007). Portfolio firms that possess similar resources and capabilities are substitutive and compete for access to the same investor resources. Because firms experience capacity constraints in the short run use of many of their resources (Levinthal and Wu, 2010), a portfolio focused on relationships with similar partners has an increased potential for conflicts and congestion among the resources an investor commits to these relationships. Specifically, the cognitive resources of investor personnel working in a particular technology or product domain are limited (Cohen and Levinthal, 1990). Because these resources are primarily engaged in internal firm activities, they have limited availability for external collaborations. As a result, the specific cognitive resources required for, and used in, one collaborative relationship may be pre-empted from being used in additional relationships with similar partners or may be thinly spread across such relationships, both of which will reduce the firm's ability to learn from these similar relationships. Thus, resource constraints increase the potential for sub-additive portfolio effects related to a firm's innovation when there is little portfolio diversity. These resource constraint problems as well as portfolio sub-additivity decline as portfolio diversity increases.

Given these benefits and costs of portfolio diversity, we expect it will have an inverted U-shaped effect on a CVC investor's innovation. On the one hand, low levels of diversity provide little complementarity across relationships and thus have limited portfolio-level synergistic benefits for innovation. Even when an investor has a high degree of absorptive capacity with its portfolio firms and may 
be able to efficiently leverage investments in such absorptive capacity across partnerships, the knowledge to which the investor has access will contain little relative novelty and little value for innovation. This problem is exacerbated when portfolio firms are disinclined to share their knowledge, or when portfolios consist of similar partners, which increases resource congestion problems for investors. On the other hand, high levels of portfolio diversity lead to absorptive capacity problems, which can outweigh the benefits of access to a wide variety of novel knowledge and low partner protectiveness, generating a sub-additive portfolio effect. Although greater diversity increases opportunities to generate novel recombinations and reduces resource congestion problems, a principal limiting factor in producing innovations is an organization's ability to transform potentially novel recombinations into usable innovations (Weitzman, 1998). Also, cognitive and informational overload and diseconomies of scale arising from a diverse portfolio can limit the ease with which firms can recognize, evaluate, and utilize the external knowledge elements (Ahuja and Lampert, 2001). As knowledge elements become diverse, the probability of their successful recombination declines, with excessive diversity negatively affecting innovation (Fleming and Sorenson, 2001). An investor's innovation efforts will benefit from a balance of access to a moderate degree of novel knowledge, moderately efficient and effective relative absorptive capacity, moderately protective partners, and limited resource congestion.

Hypothesis 1 (H1): The diversity of a firm's portfolio of new ventures will have an inverted U-shaped relationship with its innovation performance.

\subsection{Portfolio depth}

Successful recombinations typically involve knowledge components that are salient, accessible, and well understood (Fleming, 2001). Therefore, recombining knowledge elements across firm boundaries from a portfolio of young ventures can be challenging. The technological knowledge possessed by startups may not be sufficiently well developed or embedded in routines due to the lack of formal processes which is the hallmark of entrepreneurial firms (Stinchcombe, 1965). Thus, an investor may be unable to detect which elements of a startup's knowledge will yield useful recombinations. The inability to evaluate the recombinatorial potential of a startup's technological knowledge can decrease an investor's incentive to collaborate in learning from the startup because an increase in the depth of a firm's knowledge reduces potential recipients' uncertainty about its quality, making it a more attractive knowledge source (Tallman and Phene, 2007). Even when an investor is able to identify promising knowledge elements for recombination, 
the investor's ability to transfer and assimilate this knowledge is contingent upon the depth of a partner's knowledge (Baum et al., 2000; Stuart, 2000). The deeper the technological knowledge of a firm, the better is its ability to articulate, communicate, and illustrate how its knowledge can be utilized, increasing its capacity to transfer knowledge (Zhao and Anand, 2009). Thus, firms with deeper knowledge may be more effective at transferring it and may be a richer source of knowledge. Prior research shows that when firms access knowledge from sources with deeper knowledge bases they are better able to transfer and recombine it (Almeida and Phene, 2004; Baum et al., 2000; Salomon and Martin, 2008; Stuart, 2000).

The depth of knowledge in a CVC investor's portfolio will mitigate some of the costs and amplify some of the benefits of diversity, thus positively moderating diversity's effect on innovation. Specifically, increasing depth of portfolio firms' technological knowledge should enhance an investor's relative absorptive capacity and complement its ability to benefit from diverse partner knowledge by increasing the effective detection, transfer and assimilation of this knowledge. Thus, firms with deeper technological knowledge may be more effective at transferring their knowledge and may be a richer source of knowledge. This also increases the benefit of reduced protectiveness associated with increasing portfolio diversity because ventures with deeper knowledge bases should have more to teach, be better teachers, and be more willing to teach. This is particularly important in the CVC context in which ventures that pursue similar and substitutive technologies relative to corporate investors are typically unwilling to share their technological knowledge with investors due to concerns of expropriation (Dushnitsky and Lenox, 2009). Increasing diversity diminishes these concerns, thus increasing cooperation, while increasing depth improves an investor's ability to learn from diverse ventures. Further, the costs of diversity are diminished because technologically-richer ventures are able to share the cognitive load and actively participate in helping the investing firm understand their technology, thereby facilitating its combination with the investor's knowledge (Gavetti and Levinthal, 2000; Katila and Ahuja, 2002). In sum, deeper partner knowledge increases a firm's ability to benefit from increasingly diverse partners, enhancing the positive effect and diminishing the negative effect of portfolio diversity on its innovation performance.

Hypothesis 2 (H2): The depth of technological knowledge in a firm's portfolio of new ventures will moderate the inverted U-shaped relationship between porffolio diversity and innovation performance. Specifically, increasing porffolio depth will improve the positive effects of diversity, increase the amplitude of the effects of diversity, and reduce the negative effects of 
diversity on firm innovation performance.

\subsection{Portfolio Firms' Partners}

Beyond the internal knowledge resources of its portfolio of ventures, a focal investor can also benefit from the knowledge spillovers to which the ventures have access. In addition to the relationship it maintains with a focal investor, a venture may also maintain collaborative relationships with other firms (Stuart et al., 1999; Wadhwa and Kotha, 2006). Prior research shows that an important mechanism through which resource-constrained ventures are able to access complementary external knowledge resources and build their internal knowledge bases is the network of alliances they form (Baum et al., 2000; Shan et al., 1994). Ventures with a larger number of alliance partners are privy to more information and know-how than ventures with fewer alliance partners (Powell et al., 1996). Alliance partners can also provide firms with valuable know-how about how to effectively exchange knowledge and information across firm boundaries and benefit from knowledge spillovers (Dyer and Singh, 1998; Kale et al., 2000; Lavie and Rosenkopf, 2006).

An investor's direct CVC ties with its portfolio ventures can thus provide it with access to the knowledge spillovers derived from the ventures' other alliance partners (Ahuja, 2000). An increase in such spillovers provides an investing firm with access to a greater depth of knowledge in its portfolio. Indeed, a primary insight from research on networks of interorganizational relationships is that such ties serve as pipes through which information, know-how and other resources flow and firms that are more connected, both directly and indirectly, to others have greater and timelier access to such resources (Phelps et al., 2012). Indirect ties enable a firm to potentially gather greater information about technological trajectories and the success and failure of other firms' research efforts and act as an information processing and screening mechanism (Leonard-Barton, 1995), thereby focusing the attention of the focal firm on those knowledge elements that are more relevant and likely to lead to successful recombinations (Ahuja, 2000). Consistent with these arguments, prior research finds a positive relationship between a firm's indirect knowledge sharing relationships and its innovation performance (Phelps et al., 2012).

The depth of knowledge spillovers to which a CVC investor has access via its indirect links to its portfolio ventures' partners should moderate the influence of portfolio diversity on investor innovation by conditioning diversity's costs and benefits. The benefits of portfolio diversity are enhanced because the knowledge spillovers from the ventures' partners deepens the knowledge available in the portfolio, allowing 
the investor to investigate more deeply and better understand the different knowledge domains, thereby increasing its ability to integrate and combine the knowledge with its own (Gavetti and Levinthal, 2000; Katila and Ahuja, 2002). The increased richness of knowledge in a portfolio that results from the ventures' increased connectedness increases the potential for diverse knowledge to be recombined in novel ways. In addition, the benefit of reduced protectiveness associated with increasing portfolio diversity is enhanced because portfolio ventures with more partners also acquire valuable collaborative experience that enables them to exchange and transfer their knowledge more efficiently and effectively with the focal investor. As portfolio ventures become better at forming and maintaining alliances with their other partners, they also help mitigate the costs associated with a diverse portfolio by compensating for the cognitive overload experienced by the corporate investor. In sum, access to a portfolio with a highly connected portfolio of ventures can enhance the ability of the corporate investor to learn from an increasingly diverse portfolio.

Hypothesis 3 (H3): The combined number of alliance partners of firm's portfolio of new ventures will moderate the inverted $U$ shaped relationship between portfolio diversity and firm innovation performance. Specifically, more portfolio partners will improve the positive effects of diversity, increase the amplitude of the effects of diversity, and reduce the negative effects of diversity on firm innovation performance.

\section{Methods}

We chose the global telecommunications equipment industry (SIC 366: "Communications Equipment") as the setting for this study for two reasons. First, in the last three decades this industry experienced substantial technological and competitive changes (Amesse et al., 2004), which resulted in growing CVC investing by incumbents (Dushnitsky, 2006). Second, because we use patent data (as explained below), we chose an industry where firms routinely and systematically patent their inventions (Hagedoorn and Cloodt, 2003). Focusing on one industry allows us to control for industry-specific intellectual property regimes, which influence firm innovation (Lavie et al., 2010).

Many practical considerations influenced our sample construction. To control for unobserved differences in firms' innovation performance, we needed sufficient time varying data on the same firms. We chose the period 1989-2000. We chose 1989 as the initial year because: (1) it coincides with the beginning of a wave of increasing CVC investment among telecom firms (Dushnitsky, 2006) and (2) financial data on many non-U.S. sample firms were unavailable prior to this period. Given the lag between the application 
date of a patent and its granting, we ended the sample in 2000 . Nearly $99 \%$ of all patent applications are decided upon by the USPTO within five years of application (Hall et al., 2001), essentially eliminating the risk that our patent data are right-censored. Given the one-year lag between independent and dependent variables, 1999 is the last year we observed investments. We excluded the year 2000 because it exhibited a major spike in VC investments that could bias our results.

To ensure availability and reliability of financial data, we limited the sample frame to public firms. Following prior research (e.g., Dushnitsky and Lenox, 2005; Keil et al., 2008), we used the VentureXpert database, the official database of the National Venture Capital Association (NVCA), to construct our sample of corporate investors. Corporate investors are defined as non-financial public firms who directly invested capital in private, entrepreneurial firms. We identified those corporate investors who had made at least one CVC investment during the sample period. Our final sample consists of an unbalanced panel of 40 publicly traded telecom-equipment manufacturers headquartered in 11 countries and 417 firm-year observations.

\subsection{Data and measures}

We used patents to assess investor innovation because patents are valid and robust indicators of knowledge creation (Trajtenberg, 1987). One way knowledge creation is instantiated is in the form of inventions (Griliches, 1990). While inventions can be used to trace an organization's knowledge creation, patents offer a measure of novel invention that is externally validated through the patent examination process (Griliches, 1990). A patent application represents a positive expectation by an inventor of the economic significance of the invention because obtaining such protection is costly (Griliches, 1990). Thus, patents reflect the output of a firm's innovation process. While patents measure a codifiable portion of a firm's technological knowledge, they correlate with measures that incorporate tacit knowledge and are a good measure of innovation in the telecom equipment industry (Hagedoorn and Cloodt, 2003).

We obtained U.S. patents from the Delphion database belonging to Thomson Reuters. Using patents from one country maintains consistency, reliability and comparability across firms (Griliches, 1990). U.S. patents are a good data source because of the rigor and procedural fairness used in granting them, firms' strong incentives to gain patent protection in the world's largest market, the high quality of services provided by the USPTO, and the U.S.'s reputation for providing effective IP protection (Pavitt, 1988). Although many of the sample firms are headquartered outside the U.S., all have established a substantial 
presence in the U.S. telecommunications equipment market. Schmoch and Schnoring (1994) showed that the major multinational telecommunications equipment manufacturers from Japan and Europe, all of which are in our sample, actively pursued U.S. patent protection in the late 1980 s.

We used the application date to assign granted patents to firms because it captures the timing of knowledge creation (Griliches, 1990). Because patents are often assigned to subsidiaries, which may change names or merge, we carefully aggregated patents to the firm level. We identified all divisions, subsidiaries, and joint ventures of each sample firm as of 1980 using Who Owns Whom and Directory of Corporate Affiliations and then traced each firm's history to account for name changes, division names, divestments, acquisitions, and JVs. We used this master list of entities to assign patents to sample firms.

We collected CVC data from the VentureXpert database and obtained investor firm financial data from Compustat, annual reports, SEC filings, the Japan Company Handbook, Worldscope, and Global Vantage. Investor acquisition data and investor and target alliance data were obtained through systematic searches of the SDC M\&A database, SDC alliance database, Factiva, Lexis-Nexis, and Dialog.

\subsubsection{Dependent variable}

Following prior research (Lahiri, 2010; Trajtenberg, 1990; Yang et al., 2010; Ziedonis, 2007), we measured investor innovation performance using forward citation-weighted patent counts. Citations received by a patent reflect the intellectual lineage of the patent and the impact that the patent has on subsequent technological development (Ketchen et al., 2013). Thus, forward citations that a firm's patents receive from subsequent patents have been acknowledged as a valid measure of technological importance, and therefore, the quality and economic value of the underlying invention (Hall et al., 2005; Ketchen et al., 2013; Trajtenberg, 1990). We first identified the set of all patents applied for (and subsequently granted) by investor $i$ in year $t$. We then identified all the forward citations received by this set of patents in the next 7 years, as well as until the end of 2013. We excluded self-citations by eliminating all forward citations that belonged to the same firm $i$. Innovation performance was operationalized as the total number of forward citations that a firm $i$ s patents applied for in year $t$ received in the next seven years. We also computed the total number of forward citations that a firm is patents applied for in year $t$ received until the end of 2013.

\subsubsection{Explanatory variables}

Following Wassmer's (2010) recommendation, we include only existing partnerships in our portfolio 
measures. In constructing these measures, we include all startups in which a firm invested during the four years prior to and including the focal year. With the exception of publicly reported events such as an IPO or acquisition, it is often difficult to observe when a venture exits an investor's portfolio. We assumed that ventures remain in a firm's portfolio for four years from the date of initial investment for two reasons. First, we exhaustively searched a variety of data sources such as Lexis Nexis, Factiva, Internet archives, company websites, SEC documents, and IPO and acquisition databases and were able to identify the actual exit dates for 82 of the 353 portfolio firms in the sample and found that the average time between initial CVC investment and portfolio exit for these 82 firms was nearly four years. Second, research on the influence of interfirm relationships, such as alliances and acquisitions, has found that the effect of these relationships on firm innovation endures for three to five years (Ahuja and Katila, 2001; Stuart, 2000). Assuming a 4-year duration for an inter-organizational relationship is in line with standard practice in inter-organizational research given the substantial difficulties in identifying termination/exit from secondary sources.

To measure portfolio diversity, we adapted Rodan and Galunic's (2004) measure of knowledge heterogeneity, a measure that incorporates information on the knowledge distance between a focal actor and each of its partners and the distance among the partners. Although patent data would have been ideal to compute knowledge distance, we are unable to use patents because more than $50 \%$ of our sample ventures do not hold patents at the time they received investments from corporate investors. Following other studies that faced the same dilemma (Dushnitsky and Lenox, 2005; Jiang et al., 2010; Keil et al., 2008; Lin and Lee, 2011), we use SIC codes to capture the knowledge similarity between firm pairs as this information was consistently available for all the startups in our sample.

To assess diversity of an investor's portfolio firms, we collected the four-digit standard industry classification (SIC) codes in which the corporate investors and startups were active during the period of study. Consistent with prior research, we assume that different industries reflect different characteristic bundles of firm resources and capabilities (Baum et al., 2000; Goerzen and Beamish, 2005; Jiang et al., 2010; Lin and Lee, 2011). We began at the dyad-level and measured the distance between a pair of firms by adapting an index developed by Jaffe (1986). For each firm-year, we identified the four-digit SIC codes from the Compustat database in which the investor firm was active. Because privately held ventures are not allocated SIC codes until they go public, we used VentureXpert's concordance mapping each venture's 
industry to an SIC code. A similar approach has been used for private ventures in the past (Dushnitsky and Shaver, 2009). This distribution locates each firm in a multidimensional space based on four-digit SICs, captured by a $K$-dimensional vector $f_{i}=\left(f_{i 1} \ldots f_{i k}\right)$, where $f_{i k}$ represents the fraction of all of firm $i$ 's four-digit SICs in industry class k. Consistent with Bryce and Winter (2009), this approach assumes that each fourdigit SIC deploys a different technology and thus the distribution of a firm's four-digit SICs reflects the distribution of its technical knowledge. The subscript $i t-1$ below indicates that the independent variables for firm $i$ are lagged one year relative to the dependent variable.

The distance, $d$, between investor firm $i$ and portfolio firm $j$ in year $t$ was calculated as:

$$
d_{i j t}=1-\left[\sum_{k=1}^{K} f_{i k} f_{j k} /\left(\sum_{k=1}^{K} f_{i k}{ }^{2}\right)^{1 / 2}\left(\sum_{k=1}^{K} f_{j k}{ }^{2}\right)^{1 / 2}\right]
$$

where: $f_{i k}=$ fraction of all of investor $i$ 's four-digit SICs in industry class $k_{.}, f_{j k}=$ fraction of all of venture $j$ 's four-digit SICs in industry class k., and $K=$ Total number of SIC classes that the investor and venture were present in. The distance, $d$, between investor firm $i$ and portfolio firm $j$ in year $t$, is bounded between 0 (complete similarity) and 1 (complete dissimilarity), and is symmetric for the two firms. We used these pairwise distance values to construct a distance matrix, $D_{t}$, for each year $t$ in the sample. These square and symmetric matrices reflect the SIC-based distances between all possible pairwise combinations of sample firms (i.e., investors and ventures) in a given year.

To compute portfolio diversity, we first calculated a value of the uniqueness of each portfolio firm $j$ in corporate investor $i$ s portfolio in year $t-1$. The uniqueness of a portfolio firm, $j$, is a function of the uniqueness of all other ventures present in investor $i$ s portfolio in that year, and portfolio firm $j$ s distance from them. Following Rodan and Galunic (2004), the uniqueness of a portfolio firm $j$, $u_{j}$, is defined as: $\lambda u_{j}=\sum_{k} d_{j k} * u_{k}$. Doing so yields a recursive system of equations whereby the uniqueness of one venture in an investor's portfolio depends recursively on the venture's distance from all other ventures in the investor's portfolio in that year. For example, consider an investor with three ventures $\mathrm{X}, \mathrm{Y}$, and Z in its portfolio: the extent to which the portfolio is diverse and exposes the investor to a wider range of unique knowledge elements will not only depend on how different the knowledge resources of each of the three ventures are from the investor but also on how different the knowledge resources of ventures $\mathrm{X}, \mathrm{Y}$, and Z 
are from each other. Thus, the uniqueness of each portfolio firm is found in the solution of the eigen equation: $\lambda U=D U$, where $\mathrm{D}$ is the matrix of pairwise distances between the investor $i$ and each of its portfolio ventures, $U$ is an eigenvector of $D$ and $\lambda$ is its eigenvalue. ${ }^{1}$ The elements of $U$ are the uniqueness measures for investor $i$ and its portfolio ventures. For a matrix $\mathrm{D}$ of size $n \mathrm{X} n$, the solution contains $n$ eigenvalues. We use the largest eigenvalue to find the eigenvector U. Following Rodan and Galunic (2004) and Phelps (2010), we measure the diversity available to investor $i$ in its portfolio of ventures in year $t-1$ as:

$$
\text { PortfolioDiversity }_{i t-1}=\frac{1}{N} \sum_{j=1}^{N} d_{i j} \lambda u_{j} \text {, }
$$

where $d_{i j}$ is the SIC-based distance of venture $j$ from investor $i$ and $\lambda u_{j}$ is $j$ s uniqueness score computed for all of $i$ s portfolio firms. The $1 / N$ term compensates for the fact that lambda increases linearly with portfolio size. The measure captures the SIC-based distance between the focal investor and each of its portfolio firms as well as the SIC-based distances among the portfolio firms. Portfolio diversity increases with the distance between investor $i$ and its portfolio ventures and with the distance among the ventures. In order to compute the 4-year portfolio for each focal investor from 1989 onwards, we started collecting data on the investor's SIC codes and its portfolio companies from 1986 onwards.

Drawing on the innovation search and interorganizational learning literatures, we characterized a CVC investor's portfolio of ventures as an extramural knowledge search space to which the investor has access as a result of its investment relationships with the ventures. Knowledge depth refers to the accumulated stock of knowledge accessible by an actor in a particular search space (Katila and Ahuja, 2002; Laursen and Salter, 2006). Accordingly, we define the depth of knowledge in a CVC portfolio as the accumulated stock of technological knowledge possessed by the ventures in the portfolio. Building on prior research (Baum et al., 2000; Stuart, 2000; Tallman and Phene, 2007), we use patent data to observe and quantify the depth of technical knowledge possessed by an investor's venture partners. Using USPTO data from the Delphion database, we operationalized Porffolio depth as the average number of patents owned by the ventures in which firm $i$ invested during the prior four years, including year $t-1$. For young ventures, patents are often considered as positive signals of their quality and technological competence (Hsu and

\footnotetext{
${ }^{1}$ Lambda $(\lambda)$, a constant, is required to obtain a nonzero solution. To ensure non-negative uniqueness values, the largest eigenvalue $(\lambda)$ is used (Bonacich, 1987).
} 
Ziedonis, 2013). Because patents include detailed explanations, employing well-understood, formal, and symbolic language, for a novel and valuable solution to a technical problem, patents indicate that a firm has, at least to some extent, codified its technological knowledge and validated the potential utility of that knowledge (Jensen et al., 2007). Because the cognitive effort made in codifying knowledge results in a richer and deeper understanding of the knowledge and the creation of new knowledge (Cowan et al., 2000; Zollo and Winter, 2002), ventures that have invested in patenting their knowledge should be a richer source of knowledge. In this way, patents are a credible signal of the quality of a firm's codified knowledge base (Cohendet and Meyer Krahmer, 2001) and "convey information about the lines of research a firm is conducting and how quickly the research is proceeding” (p. 646, Long, 2002). The extent to which a venture has patented its technical inventions thus reflects is depth of technological knowledge (Griliches, 1990).

Portfolio firms' partners was computed as the average number of alliance partners, including relationships with other CVC investors, of the portfolio of all startups in which firm $i$ invested during the four years prior to and including year $t-1$. The number of alliance partners of a venture reflect the indirect ties that the focal investor has access to through its relationship with the venture (Ahuja, 2000). The data were obtained from SDC alliances database, VentureXpert, and triangulated by searching the Lexis Nexis and Factiva databases, as well as company websites.

\subsubsection{Control variables}

We control for potential confounding factors. First, prior venturing experience provides the basis for a venturing capability, which can result in improved learning from portfolio firms (Keil, 2004), and can capture otherwise unobserved differences in an investor's ability to benefit from CVC investments. We control for investor is CVC experience in year $t-1$ as the log of the cumulative count of CVC investments since its first investment, weighted by the time since each investment was made. These data were obtained from the VentureXpert database. Second, using Compustat data, we control for investor size, R\&D, slack and age for the following respective reasons: (a) size can have negative and positive effects on firm innovation (Cohen and Levin, 1989), (b) a firm's R\&D expenditures are investments in knowledge creation (Griliches, 1990) and may increase its ability to absorb extramural knowledge (Cohen and Levinthal, 1990), (c) firms with slack resources may participate in more exploratory search (Greve, 2007), which can increase innovation performance (Nohria and Gulati, 1996), and (d) as firms age, they tend to exploit their existing 
technological competencies rather than explore new and unfamiliar technologies (Sorensen and Stuart, 2000). For a firm $i$ in year $t-1$, we operationalize firm size using the natural log of sales in $\$$ US million (Investor Sales); we measure firm R\&D using R\&D Intensity (R\&D expenditures/sales); we follow prior research (e.g., Bourgeois and Singh, 1983) and measure a firm's unabsorbed slack resources using its year end current ratio (Investor Current Ratio); and Investor Age as the number of years from the firm's founding. Third, we control for Investor Alliances and Acquisitions because they represent alternative extramural sources of knowledge that can influence firm innovation (Ahuja and Katila, 2001; Stuart, 2000) and because their use is correlated with the use of CVC (van de Vrande et al., 2009). We control for the number of acquisitions made by firm $i$ and for the number of alliances (excluding those involving portfolio firms) formed by firm $i$ during the four years prior to and including year $t-1$. We used straight-line depreciation to account for the declining influence of acquisitions and alliances over time.

Next, we control for Investor Technological Diversity. Increasing technological diversity may increase the potential for innovation based on internal spillovers (Garcia-Vega, 2006), and may increase a firm's ability to identify, evaluate, and absorb knowledge from external sources (Cohen and Levinthal, 1990). We measure firm $i$ s technological diversity in year $t-1$ using Hall's (2002) adjusted Herfindahl index:

Technological Diversityit-1 $=\left[1-\sum_{j=1}^{J}\left(N_{j i t} / N_{i t}\right)^{2}\right] *\left(N_{i t} / N_{i t-1}\right)$, where $\mathrm{N}_{i t-1}$ is the number of patents obtained by firm $i$ in the four years prior to and including year $t-1 . \mathrm{N}_{j i t}$ is the number of patents in primary technology class $j$ in firm $i$ s four year knowledge base. This variable may take on values between 0 (no diversity) to 1 (max. diversity). We also control for Investor Total Patents - the number of patents that were applied for by (and subsequently granted to) CVC investor $i$ in year $t-1$ because firms that patent more are at greater risk of receiving a higher number of citations (Trajtenberg, 1990). Given the one year lag between the observation of our DV and our explanatory and control variables, the patents used to compute investor patents do not overlap with the patents used to construct our DV (i.e., those patents at risk of forward citation). Finally, we control for Portfolio Size, operationalized as the number of ventures present in the CVC portfolio of investor $i$ in year $t-1$.

\subsection{Model specification and estimation}


Our dependent variable is a count variable, which exhibits significant over-dispersion, and takes on only non-negative integer values. Thus, we use a negative binomial model, which is a generalization of the Poisson model and allows for overdispersion by incorporating an individual, unobserved effect into the conditional mean (Hausman et al., 1984). The negative binomial panel estimator accommodates explicit control of persistent individual unobserved effects through both fixed and random effects. In this study, unobserved heterogeneity may stem from unmeasured differences among observationally equivalent firms that affect their innovation performance, or from unmeasured, systematic time period effects. Because unobserved heterogeneity can result in specification error (Heckman, 1979), we employ two strategies to control for it. First, we include year fixed effects to control for systematic period effects that may affect all sampled firms' innovation performance, such as year-to-year differences in environmental dynamism, competitive intensity and macroeconomic conditions (Lavie et al., 2010). Second, we employ firm effects to control for unobserved firm differences in innovation, such as those caused by differences in CVC program structures and objectives. ${ }^{2}$ To check the appropriateness of using random effects estimation, which assumes that unobserved firm effect is not correlated with the regressors, we used the Hausman test (1978), which did not converge. Therefore, we report results for the more conservative fixed effects estimation. We lag all covariates by one year to reduce concerns about reverse causality.

\section{Insert Tables 1, 2, and 3 and Figures 1 and 2 about here}

\section{Results}

Table 1 presents the descriptive statistics and correlations. Investor CVC Experience, Investor Size and Portfolio Diversity were $\log$ transformed to reduce skewness and kurtosis. Table 2 displays the negative binomial panel regression results using firm fixed effects. Because Hausman tests did not converge for all

\footnotetext{
${ }^{2}$ CVC program objectives determine the intent of CVC investments in terms of exploration or exploitation. That is, some firms pursue exploitation in their CVC programs, while others pursue exploration and some pursue both (Dushnitsky, 2006; Maula, 2007). These program objectives are stable over long periods of time (Dushnitsky, 2006; Dushnitsky and Shaver, 2009). Consequently, firm effects (either random or fixed) will capture the influence of unobserved differences in firms' CVC program objectives on their exploratory knowledge creation. We were able to find additional information on objectives of 13 of the 40 investor firms by searching archival sources and interviews we conducted with some CVC program managers. This data increases our confidence that the vast majority of investments made for technology-related reasons and these program objectives remained stable over time. Consequently, our use of firm effects effectively controls for unobserved differences in CVC program objectives.
} 
models, we report the more conservative results using firm fixed effects after removing the time invariant variables (pre-sample and investor region) from the models. The results using random effects were consistent in terms of significance and signs and are available upon request.

In Table 2, Model 1 is the baseline model with control variables. Models 2 and 3 introduce portfolio diversity and its square. To test the moderating effect of portfolio depth and portfolio firms' partners, each moderator variable was interacted with the linear and squared term of portfolio diversity. Model 4 introduces the two moderating variables without any interactions. Models 5 and 6 show these interaction effects entered separately. Model 7 is the full model with all interaction terms. The Log likelihood and Wald Tests indicate improvement in model fit relative to the baseline model and overall model fit, respectively. Although not reported, all models include year dummies.

Hypothesis 1 predicted an inverted U-shaped relationship between portfolio diversity and firm innovation performance. Evidence of an inverted U-shaped effect requires that the second order (quadratic) term be negative and significant while the lower order (linear) term does not need to be significant (page 6567, Aiken and West, 1991). When portfolio diversity and its square are introduced together in Models 3-7, portfolio diversity is positive and significant and portfolio diversity squared is consistently negative and significant. Moreover, using parameter estimates from the final model (Model 7, Table 2), the maximum value of innovation occurs when the logged portfolio diversity is 0.407 , which is within the sample range of 0.00-1.89. Thus, we find support for hypothesis 1.

Hypothesis 2 predicted that portfolio depth would moderate the relationship between portfolio diversity and investor innovation. In Models 5 and 7, the interaction between portfolio diversity squared and portfolio depth is positive and significant. To better interpret the interaction term, we graphed the interaction effect using the procedure outlined in Aiken and West (1991). Figure 1 shows that, at low and high levels of portfolio diversity, higher levels of portfolio depth enhance the influence of portfolio diversity on innovation performance. At a low level of diversity, increasing portfolio depth increases the benefits of portfolio diversity for a corporate investor's innovation. Greater portfolio depth mitigates the deleterious 
effect of excessive portfolio diversity. Further, the amplitude of innovation performance is higher for deeper portfolios at all levels of portfolio diversity. Thus, hypothesis 2 is supported.

Hypothesis 3 predicted that number of portfolio firms' partners would moderate the relationship between portfolio diversity and investor innovation. In Models 6 and 7, the interaction between portfolio diversity squared and portfolio partners is positive and significant. We graphed the interaction effect (Figure 2), which shows that at high (low) levels of portfolio diversity, greater number of portfolio partners enhances (weakens) the influence of portfolio diversity on innovation performance. Thus, more portfolio partners appear to mitigate the deleterious effect of excessive portfolio diversity only at higher levels of portfolio diversity. Thus, we find some support for hypothesis 3.

Multicollinearity may be a concern because we interact the square of portfolio diversity and its linear version multiple times with portfolio knowledge codification and knowledge maturity. Collinearity increases the standard errors of parameter estimates and reduces the likelihood of finding statistically significant effects. Our results are conservative because the squared diversity term remains significant in the full model even when multiple interactions involving it are entered. Because collinearity does not affect the precision of the estimates of higher order (i.e., interaction) variables (Gujarati, 2003), it should not adversely affect our results. We used the STATA command coldiag2 and verified that the condition number and condition indices were well below the recommended cutoffs of 30 and 20 respectively (Belsley et al., 1980). We found that in the presence of higher order and interaction terms, the condition number was 39.19, which drops to 17.53 when the higher order terms and interaction terms are removed.

\subsection{Robustness Analyses}

We conducted additional robustness analyses. First, we considered the potential influence of selfselection. Since we are unable to observe portfolio-related variables for those firm-years in which a firm did not make a CVC investment in the prior four years, these observations are censored because investors have self-selected into and out of making CVC investments. This introduces the possibility of a bias due to selfselection. To control for this bias, we restricted our sample to the uncensored observations (i.e., those firm- 
years in which firm $i$ made at least one CVC investment in the four years leading up to and including year $t$ 1) and reran our regressions (Models 1A-7A, Table 3). The results reported in Models 1A-7A are similar to and consistent with those presented in Models 1-7 of Table 2. We graphed the relationship from Model 7A for a comparison with Model 7 (Figure 1). The quadratic term of portfolio diversity is still strongly significant, suggesting that the inverted-U relationship between portfolio diversity and investor innovation

still holds. Second, we computed two additional measures of diversity - within-portfolio diversity (which captures how different the industries of portfolio ventures are from each other), and averaged-portfolio diversity (which averages the differences between the industry of each portfolio venture and the industry of the CVC investor). Results with the within-portfolio diversity are similar in sign and significance to those we obtain with our single measure of diversity, while averaged-portfolio diversity does not show any effect on investor innovation. Finally, we reran all the regressions with random effects specification and the results are consistent with those reported in Tables 2 and 3.

\section{Contributions, limitations, and future research}

This study examined the influence of the resource composition of a corporate investor's portfolio of CVC investment relationships with startups on its innovation performance. Our results suggest that diversity in resources available to a focal corporate investor via its portfolio of ventures as well as the characteristics of the knowledge resources of the portfolio ventures have important implications for the corporate investors' ability to generate higher quality innovations. Specifically, we find that there is an inverse U-shaped relationship between the diversity of resources available to a corporate investor in its portfolio of ventures and the investor's innovative performance. Thus, our results emphasize the benefits of moderate levels of portfolio diversity for investor innovation, and suggest that even though portfolio diversity is beneficial for innovation, it can also have cost implications that must be considered. Going beyond this baseline result, we examine important partner-specific contingencies that present a more nuanced picture of the portfolio-diversity -innovation relationship. We find that the benefits of portfolio diversity are enhanced and the costs of portfolio diversity mitigated when portfolio partners are rich in 
knowledge resources; that is, when they possess deeper technological knowledge and are connected to external knowledge resources via alliances. These contingencies suggest that a firm's innovation performance is indirectly impacted by the resources directly available to it through its partners and by its partners' access to resources via their other alliance relationships.

While our results are consistent with our hypotheses, we found some interesting differences in how portfolio partners' internal and external knowledge resources may impact the portfolio diversity - innovation relationship. When we examine the graphs of the relationships in Figures 1 and 2, we find that the technological depth of the portfolio partners has a predominantly positive effect across the entire range of portfolio diversity. At lower levels of diversity, portfolio depth strengthens the already positive diversityinnovation relationship, and at higher levels of diversity, depth reduces the effects of the negative diversityinnovation relationship. In contrast, even though the number of alliance partners of the portfolio has a positive effect on the diversity-innovation relationship, this effect is present mostly in the higher ranges of portfolio diversity (that is, it reduces the negative effect of the diversity-innovation relationship). At lower levels of diversity, a greater number of alliance partners appears to reduce the positive diversity-innovation relationship. We can think of one explanation for this result. It is possible that when portfolio diversity is low, and each venture is less unique, the portfolio ventures may also maintain alliances with technologically similar partners because of the propensity of firms to form alliances with technologically similar others (Stuart, 1998). In this case, the informational advantages of the focal investor's indirect ties are diminished because of redundancies in the knowledge provided by its indirect ties. Additionally, because the ventures and their other alliance partners have greater similarity to a focal investor, they may be more protective of their own knowledge and that to which they have access. This is an intriguing possibility that requires further examination.

\subsection{Contributions}

Our results contribute to prior literature in three ways. First, we contribute to research on portfolios of interfirm relationships by examining characteristics of portfolio partners. Interorganizational research has 
generally overlooked the types of interdependencies that can occur across relationships within a portfolio and the influence such interdependencies have on firm performance (Wassmer, 2010). Research on collaborative interfirm relationships has typically adopted a dyadic-level perspective, treating such ties as independent events rather than interdependent elements in a portfolio of relationships (Lavie, 2007). For example, dyadic-level research examines how differences between partners can affect firm innovation (Sampson, 2007), but ignores the differences between a firm and its partners and among the partners. Moreover, the few studies that have examined the composition of a firm's portfolio of interfirm ties have examined the independent, and thus additive, effects of partners' resources (e.g., Stuart, 2000). We add to the emerging body of work that emphasizes the importance of portfolios of relationships and examines the effect of portfolio diversity on firm innovative performance (Goerzen and Beamish, 2005; Hoehn-Weiss and Karim, 2013; Jiang et al., 2010; Mouri et al., 2012; Sarkar et al., 2009; Van de Vrande, 2013; Vassolo et al., 2004; Vasudeva and Anand, 2011). Most research that has examined the influence of interorganizational portfolio diversity on firm performance only considers the differences among a firm's partners and not their dissimilarity with the focal firm (Goerzen and Beamish, 2005; Hoehn-Weiss and Karim, 2013; Jiang et al., 2010; Van de Vrande, 2013). In contrast, using a network based measure of diversity, we studied the dissimilarities between a firm and its partners and among the partners in the portfolio. This allowed us to evaluate the conditions under which relationships in a portfolio are complementary or substitutive and therefore yield super-additive or sub-additive effects at the portfolio level (Vassolo et al., 2004). We found a curvilinear relationship between a firm's innovation performance and its portfolio diversity. Moreover, in contrast to prior research, which overlooks how attributes of the resources possessed by a firm's portfolio of partners may moderate the portfolio's effect on firm performance, we found the influence of portfolio diversity on firm innovation depends on the quality of partners' technological knowledge resources and the extent of their social capital. Our results contribute to an understanding of the desirable level of portfolio diversity and how firms can reduce the costs and increase the benefits of diversity for innovation.

Second, we contribute to CVC research and the broader corporate entrepreneurship literature by 
identifying conditions under which CVC investing influences innovation in established firms. Prior research on CVC and investor innovation performance has rarely examined whether or when interdependencies in portfolios of CVC investments contribute to investor innovation. Although some studies provide evidence of the existence of interdependencies among ventures within CVC portfolios and how diversity in such portfolios influences firm financial value (Lin and Lee, 2011; Yang et al., 2013), it has yet to explore how ventures within CVC portfolios interact to influence investor innovation. As such, we respond to the call by Dess et al. (2003) to study how corporate entrepreneurship initiatives influence learning and renewal, and follow Dushnitsky's (2006) suggestion to examine the impact of CVC on aspects of firm performance beyond simple counts of innovations. We found increasing portfolio diversity generated diminishing and ultimately negative returns to firm innovation and that the extent of technological and social capital that inheres in a portfolio moderates the impact of its diversity on firm innovation performance.

Finally, our results have implications for research on open innovation. A fundamental focus of open innovation research is on understanding how organizations explore and leverage knowledge from external partners to facilitate invention and innovation (West and Bogers, 2014). Corporate venture capital represents an increasingly important tool for open innovation (Chesbrough, 2003; MacMillan et al., 2008) because most firms pursue CVC as a means to learn from innovative start-ups (Dushnitsky, 2006). Despite this widespread goal, surprisingly little research has explored the influence of CVC on investor innovation. The few studies that have done so examined the influence of the amount of CVC activity (Dushnitsky and Lenox, 2005; Wadhwa and Kotha, 2006) or have employed a dyadic perspective (Schildt et al., 2005; Smith and Shah, 2013). Research examining the link between CVC and corporate investor innovation has not examined the influence of CVC portfolio diversity or how this influence is conditioned by other characteristics of the portfolio firms. Our finding of an inverted U-shaped effect of portfolio diversity on investor innovation is consistent with previous open innovation research that finds a similar relationship between the breadth of external knowledge sources searched and firm innovation (Laursen and Salter, 2006). Open innovation research has, however, largely ignored how the benefits and costs of external 
knowledge sources for firm innovation are moderated, particularly by characteristics of the knowledge sources searched (West and Bogers, 2014). Thus, our results advance open innovation research by identifying the conditions under which CVC portfolios influence investor innovation.

\subsection{Limitations and future research}

Despite its contributions, this study has limitations. First, we were unable to observe actual knowledge flows between CVC investors and their portfolio firms. Following research on interfirm relationships and firm innovation, we infer such flows based on partner firms' characteristics. While interfirm learning research has used cross-citations between partners' patents to observe knowledge flows, we were unable to use this approach because roughly $50 \%$ of our sample startups did not have patents upon investment. Second, the use of patents to proxy for knowledge creation has limitations. Our use of granted patents limits our observation to inventions that have been validated by an impartial third party. Thus, we do not capture all knowledge creation by sample firms. Firms may patent valuable knowledge for unobserved reasons, such as in anticipation of partnering to appropriate the greater economic value associated with such novel inventions. While our findings may be influenced by such unobserved variation, our use of firm effects, numerous control variables, and a one-year lag between investment and patenting help reduce the likelihood of such biases. Third, due to data limitations, we were unable to control for the size of the equity stake held by corporate investors in startups. While equity stake size may influence a corporate investor's ability to access knowledge in a venture, we believe our inability to observe equity stake size does not influence our results. CVC investors in the U.S. typically avoid acquiring more than $20 \%$ of a venture to avoid the required use of equity accounting rules (Basu et al., 2011; Myrick, 1986), which suggests our observed CVC ties do not vary substantially in equity stake size. Finally, the generalizability of the findings may be a concern. Because the use of patents differs across industries (Levin et al., 1987), we limited our study to a single high-tech industry. In high-technology industries with rapid technological change, few firms are able to build new competences without using external knowledge (Teece et al., 1997). Although this suggests our findings may apply to other high-tech settings, researchers should assess the 
generalizability of our results.

Our results suggest some interesting opportunities for future research. This study examined only portfolios of CVC investments rather than the broader set of formal and informal external relationships that a firm can engage in. Our choice was driven by the gaps in extant research on CVC investment, some methodological advantages that the CVC context provides, and important differences between CVC investments and other external knowledge-sourcing initiatives such as alliances and M\&A. Future research could examine how portfolios of different types of interfirm relationships taken together impact firm innovation and how aggregate resources, capabilities, and other attributes of a firm's portfolio of partners affects its performance (Lavie, 2007). Second, although we show that portfolio diversity influences an investor's innovative performance, a lack of innovative outcomes need not imply a failure of the investor's CVC program and firms may employ CVC investments as a successful, non-knowledge creating, investment strategy. Because corporate investors may sometimes invest in ventures for reasons other than access to new technologies (Dushnitsky, 2006), they may obtain benefits independent of the effect of CVC portfolios on firm innovation. For example, CVC investments may lead to strategic renewal for investors by providing valuable knowledge about new product- and geographic markets. Understanding the conditions under which this occurs is a valuable question for future research. 


\section{References}

Ahuja G., 2000. Collaboration networks, structural holes, and innovation: A longitudinal study. Administrative Science Quarterly. 45: 425-455.

Ahuja G., Katila R., 2001. Technological acquisitions and the innovation performance of acquiring firms: a longitudinal study. Strategic Management Journal. 22: 197-220.

Ahuja G., Lampert C.M., 2001. Entrepreneurship in the large corporation: a longitudinal study of how established firms create breakthrough inventions. Strategic Management Journal. 22: 521-543.

Ahuja G., Lampert C.M., Tandon V., 2008. Moving Beyond Schumpeter: Managerial Research on the Determinants of Technological Innovation. Academy of Management Annals. 2 1-98.

Aiken L.S., West S.G., 1991. Multiple Regression: Testing and Interpreting Interactions. Newbury Park: Sage. Almeida P., Phene A., 2004. Subsidiaries and knowledge creation: the influence of the MNC and host country on innovation. Strategic Management Journal. 25: 847-864.

Amesse F., Latour R., Rebolledo C., Séguin-Dulude L., 2004. The telecommunications equipment industry in the 1990s: from alliances to mergers and acquisitions. Technovation. 24: 885-897.

Anand J., Oriani R., Vassolo R.S., 2007. Managing a portfolio of real options. Advances in Strategic Management. 24. Basu S., Phelps C., Kotha S., 2011. Towards understanding who makes corporate venture capital investments and why. Journal of Business Venturing. 26: 153-171.

Baum J.A.C., Calabrese T., Silverman B.S., 2000. Don't go it alone: Alliance network composition and startups' performance in Canadian biotechnology. Strategic Management Journal. 21: 267-294.

Belsley D.A., Kuh E., Welsch R.E., 1980. Regression Diagnostics: Identifying Influential Data and Sources of Collinearity. New York: John Wiley and Sons.

Bonacich P., 1987. Power and Centrality: A Family of Measures. American Journal of Sociology. 92: 1170-1182.

Bourgeois L.J., Singh J.V., 1983. Organizational slack and political behavior within top management teams. Academy of Management Proceedings. 43-47.

Bryce D.J., Winter S.G., 2009. A General Interindustry Relatedness Index. Management Science. 55: 1570-1585.

Cefis E., Marsili O., 2005. A matter of life and death: innovation and firm survival. Industrial and Corporate Change. 14: 126.

Chesbrough H., 2003. Open Innovation: the new imperative for creating and profiting from technology. Boston: Harvard Business School Press.

Cohen W.M., Levin R.C., 1989. Innovation and market structure. In: Schmalensee R., Willig R. editor editors. Handbook of industrial organization. New York, NY.: Elsevier Science Pub. Co. p. 1060-1107.

Cohen W.M., Levinthal D.A., 1990. Absorptive capacity: a new perspective on learning and innovation. Administrative Science Quarterly. 35: 128-152.

Cohendet P., Meyer Krahmer F., 2001. The theoretical and policy implications of knowledge codification. Research Policy. 30: 1563-1591.

Cowan R., David P., Foray D., 2000. The explicit economics of knowledge codification and tacitness. Ind Corp Change. 9:

211-253.

Cui A., O’Connor G.C., 2012. Alliance Portfolio Resource Diversity and Firm Innovation. Journal of Marketing Theory \& Practice. 76: 24-43.

de Leeuw T., Lokshin B., Duysters G., 2014. Returns to alliance portfolio diversity: The relative effects of partner diversity on firm's innovative performance and productivity. J Bus Res. 67: 1839-1849.

Dess G.G., Ireland R.D., Zahra S.A., Floyd S.W., Janney J.J., Lane P.J., 2003. Emerging Issues in Corporate

Entrepreneurship. Journal of Management. 29: 351-378.

Dosi G., 1988. Sources, Procedures and Microeconomic Effects of Innovation. Journal of Economic Literature. XXVI: 11201171.

Dushnitsky G., 2006. Corporate venture capital: Past evidence and future directions. In: Casson M., Yeung B., Basu A., Wadeson N. editor editors. Oxford Handbook of Entrepreneurship Oxford University Press. New York. p. 387-431.

Dushnitsky G., Lavie D., 2010. How Alliance Formation Shapes Corporate Venture Capital Investment: A Resource-Based Perspective. Strategic Entrepreneurship Journal 4: 22-48.

Dushnitsky G., Lenox M.J., 2005. When Do Incumbents Learn from Entrepreneurial Ventures? Corporate Venture Capital and Investing Firm Innovation Rates. Research Policy. 34: 615-639.

Dushnitsky G., Lenox M.J., 2006. When does corporate venture capital investment create firm value? Journal of Business Venturing. 21: 753-772.

Dushnitsky G., Shaver J.M., 2009. Limitations to interorganizational knowledge acquisition: the paradox of corporate venture capital. Strategic Management Journal. 30: 1045-1064. 
Duysters G., Lokshin B., 2011. Determinants of Alliance Portfolio Complexity and Its Effect on Innovative Performance of Companies*. Journal of Product Innovation Management. 28: 570-585.

Dyer J.H., Singh H., 1998. The relational view: Cooperative strategy and sources of interorganizational competitive advantage. Academy of Management Review. 23: 660-679.

Fleming L., 2001. Recombinant uncertainty in technological search. Management Science. 47: 117-132.

Fleming L., Sorenson O., 2001. Technology as a complex adaptive system: Evidence from patent data. Research Policy. 30: 1019 - 1039.

Galunic D.C., Rodan S., 1998. Resource recombinations in the firm: knowledge structures and the potential for

Schumpeterian innovation. Strategic Management Journal. 19: 1193-1201.

Garcia-Vega M., 2006. Does technological diversification promote innovation? An empirical analysis for European firms.

Research Policy. 35: 230-246.

Gavetti G., Levinthal D.A., 2000. Looking forward and looking backward: Cognitive and experiential search. Administrative Science Quarterly. 45: 113-137.

Goerzen A., Beamish P.W., 2005. The Effect of Alliance Network Diversity on Multinational Enterprise Performance.

Strategic Management Journal. 36: 333-354.

Greve H.R., 2007. Exploration and exploitation in product innovation. Industrial and Corporate Change. Forthcoming.

Griliches Z., 1990. Patent statistics as economic indicators. Jounal of Economic Literature. 28: 1661-1707.

Gujarati D.N., 2003. Basic Econometrics. 4th ed. New York: McGraw-Hill.

Hagedoorn J., 2002. Inter-firm R\&D partnerships: an overview of major trends and patterns since 1960. Research Policy. 31: 477-492.

Hagedoorn J., Cloodt M., 2003. Measuring innovative performance: is there an advantage in using multiple indicators?

Research Policy. 32: 1365-1379.

Hagedoorn J., Narula R., 1996. Choosing organizational modes of strategic technology partnering: International and sectoral differences. Journal of International Business Studies. 27: 265.

Hall B., Jaffe A.B., Trajtenberg M., 2001. The NBER Patent Citations Datafile: Lessons, Insights and Methodological Tools. Working Paper http://wwwnberorg/papers/w8498.

Hall B.H., 2002. A note on the bias in herfindahl-type measures based on count data. In: Jaffe A.B., Trajtenberg M. editor editors. Patents, Citations, and Innovations. Cambridge, MA: MIT Press. p. 149-156.

Hall B.H., Jaffe A., Trajtenberg M., 2005. Market Value And Patent Citations. Rand Journal of Economics. 36: 16-38.

Hargadon A., Sutton R., I., 1997. Technology brokering and innovation in a product development firm. Administrative Science Quarterly. 42: 716-749.

Hausman J., Hall B., Griliches Z., 1984. Econometric Models for Count Data with and Application to Patents-R\&D

Relationship. Econometrica. 52: 909-938.

Heckman J.J., 1979. Sample selection bias as a specification error. Econometrica. 47: 153-161.

Henderson R., Clark K., 1990. Architectural innovation : The reconfiguration of existing product technologies and failure of established firms. Administrative Science Quarterly. 35: 9-30.

Hoehn-Weiss M.N., Karim S., 2013. Unpacking functional alliance portfolios: How signals of viability affect young firms' outcomes. Strategic Management Journal. n/a-n/a.

Hoffmann W.H., 2007. Strategies for managing a portfolio of alliances. Strategic Management Journal. 28: 827-856.

Hsu D.H., Ziedonis R.H., 2013. Resources as dual sources of advantage: Implications for valuing entrepreneurial-firm patents. Strategic Management Journal. 34: 761-781.

Ingram P., 2002. Interorganizational Learning. In: Baum J.A.C. editor editors. Companion to Organizations. New York:

Blackwell. p. 642-663.

Jaffe A.B., 1986. Technological Opportunity and Spillovers from R\&D: Evidence from Firms' Patents, Profits and Market

Value. Technological opportunity and spillovers from R\&D: Evidence from firms' patents, profits and market value. 76: 9841001.

Jensen M.B., Johnson B., Lorenz E., Lundvall B.A., 2007. Forms of knowledge and modes of innovation. Research Policy.

36: 680-693.

Jiang R.J., Tao Q.T., Santoro M.D., 2010. Alliance portfolio diversity and firm performance. Strategic Management Journal. 31: 1136-1144.

Kale P., Singh H., Perlmutter H., 2000. Learning and protection of proprietary assets in strategic alliances: Building relational capital. Strategic Management Journal. 21: 217-237.

Katila R., 2000. In Search of Innovation: Search Determinants of New Product Introductions. PhD Dissertation: University of Texas, Austin, TX.

Katila R., Ahuja G., 2002. Something old, something new: A longitudinal study of search behavior and new product introduction. Academy of Management Journal. 45: 1183-1194.

Keil T., 2004. Building External Corporate Venturing Capability: Initial Conditions, Learning Processes and Knowledge Management. Journal of Management Studies. 41: 799-825. 
Keil T., Maula M.V.J., Schildt H.A., Zahra S.A., 2008. The effect of governance modes and relatedness of external business development activities on innovative performance. Strategic Management Journal. 29: 895-907.

Ketchen D.J., Ireland R.D., Baker L.T., 2013. The Use of Archival Proxies in Strategic Management Studies: Castles Made of Sand? Organizational Research Methods. 16: 32-42.

Khanna T., Gulati R., Nohria N., 1998. The dynamics of learning alliances: Competition, cooperation, and relative scope. Strategic Management Journal. 19: 193-210.

Kogut B., Zander U., 1992. Knowledge of the firm, combinative capabilities, and the replication of technology. Organization Science. 3: 383-397.

Koka B.R., Prescott J.E., 2008. Designing alliance networks: The interacting effects of environmental change and firm strategy on alliance performance. Strategic Management Journal 29: 639-661.

Lahiri N., 2010. Geographic Distribution of R\&D Activity: How Does it Affect Innovation Quality? Academy of Management Journal. 53: 1194-1209.

Laursen K., 2012. Keep searching and you'll find: what do we know about variety creation through firms' search activities for innovation? Industrial and Corporate Change.

Laursen K., Salter A., 2006. Open for Innovation: The role of openness in explaining innovative performance among UK manufacturing firms. Strategic Management Journal. 27: 131-150.

Lavie D., 2007. Alliance portfolios and firm performance: A study of value creation and appropriation in the U.S. software industry. Strategic Management Journal. 28: 1187-1212.

Lavie D., Rosenkopf R., 2006. Balancing exploration and exploitation in alliance formation. Academy of Management Journal. 49: 797-818.

Lavie D., Stettner U., Tushman M.L., 2010. Exploration and Exploitation within and across Organizations. Academy of Management Annals. 4: 109-155.

Lee D., Kirkpatrick-Husk K., Madhavan R., 2014. Diversity in Alliance Portfolios and Performance Outcomes: A MetaAnalysis. Journal of Management.

Leonard-Barton D., 1995. Wellsprings of Knowledge: Building and Sustaining the Sources of Innovation. Cambridge, MA: HArvard Business School Press.

Levin R.C., Klevorick A.K., Nelson R.R., Winter S.G., 1987. Appropriating the returns from industrial research and development. Brookings Papers on Economic Activity. 3: 783-820.

Levinthal D.A., Wu B., 2010. Opportunity Costs and Non-Scale Free Capabilities: Profit Maximization, Corporate Scope, and Profit Margins. Strategic Management Journal, Forthcoming.

Lin S.-J., Lee J.-R., 2011. Configuring a corporate venturing portfolio to create growth value: Within-portfolio diversity and strategic linkage. Journal of Business Venturing. 26: 489-503.

Long C., 2002. Patent Signals. U Chicago Law Rev. 69: 625-679.

Lubatkin M., Florin J., Lane P., 2001. Learning together and apart: A model of reciprocal interfirm learning. Human

Relations. 54: 1353.

Luo X., Deng L., 2009. Do Birds of a Feather Flock Higher? The Effects of Partner Similarity on Innovation in Strategic Alliances in Knowledge-Intensive Industries. Journal of Management Studies. 46: 1005-1030.

MacMillan I., Roberts E., Livada V., Wang A., 2008. Corporate Venture Capital (CVC): Seeking Innovation and Strategic Growth. National Institute of Standards and Technology, U.S. Department of Commerce (NIST GCR 08-916).

Maula M., 2007. Corporate venture capital as a strategic tool. In: Landstrom H. editor editors. Handbook of research on venture capital. UK: Edward Elgar Publishing. p.

Maula M.V.J., Autio E., Murray G.C., 2009. Corporate venture capital and the balance of risks and rewards for portfolio companies. Journal of Business Venturing. 24: 274-286.

Mouri N., Sarkar M.B., Frye M., 2012. Alliance portfolios and shareholder value in post-IPO firms: The moderating roles of portfolio structure and firm-level uncertainty. Journal of Business Venturing. 27: 355-371.

Myrick T., 1986. Conflicting guidance: will accounting rules impair corporate venture capital? FE: The Magazine for Financial Executives. 34-36.

Nahapiet J., Ghoshal S., 1998. Social capital, intellectual capital and the organizational advantage. Academy of Management Review. 23: 242-266.

Nohria N., Gulati R., 1996. Is slack good or bad for performance? Academy of Management Journal. 39: 1245-1264.

Ozcan P., Eisenhardt K.M., 2009. Origin of Alliance Portfolios: Entrepreneurs, Network Strategies, and Firm Performance. Academy of Management Journal. 52: 246-279.

Pavitt K., 1988. Uses and abuses of patent statistics. In: Raan A.F.J.v. editor editors. Handbook of quanitative studies of science and technology. Amsterdam: Elsevier. p. 509-536.

Phelps C., Heidl R., Wadhwa A., 2012. Knowledge, Networks, and Knowledge Networks: A Review and Research Agenda. Journal of Management. 38: 1115-1166.

Phelps C.C., 2010. A longitudinal study of the influence of alliance network structure and composition on firm exploratory innovation. Academy of Management Journal. 53: 890-913. 
Powell W.W., Koput K.W., Smith-Doerr L., 1996. Interorganizational collaboration and the locus of innovation: Networks of learning in biotechnology. Administrative Science Quarterly. 41: 116-145.

Roberts P.W., 1999. Product innovation, product-market competition and persistent profitability in the U.S. pharmaceutical industry. Strategic Management Journal. 20 655-670.

Rodan S., Galunic C., 2004. More than network structure: How knowledge heterogeneity influences managerial performance and innovativeness. Strategic Management Journal. 25: 541-556.

Salomon R., Martin X., 2008. Learning, Knowledge Transfer, and Technology Implementation Performance: A Study of Time-to-Build in the Global Semiconductor Industry. MANAGEMENT SCIENCE. 54: 1266-1280.

Sampson R.C., 2007. R\&D Alliances and Firm performance: The impact of technological diversity and alliance organization on innovation. Academy of Management Journal. 50: 364-386.

Sarkar M., Aulakh P.S., Madhok A., 2009. Process Capabilities and Value Generation in Alliance Portfolios. Oraganization Science. 20: 583-600.

Schildt H., Maula M.V.J., Keil T., 2005. Explorative and Exploitative Learning from External Corporate Ventures.

Entrepreneurship Theory \& Practice. 29: 493-515.

Schilling M.A., Green E., 2011. Recombinant search and breakthrough idea generation: An analysis of high impact papers in the social sciences. Research Policy. 40: 1321-1331.

Schmoch U., Schnoring T., 1994. Technological strategies of telecommunications equipment manufacturers - A patent analysis. Telecommunications policy. 18: 397-413.

Shan W., Walker G., Kogut B., 1994. Interfirm cooperation and startup innovation in the biotechnology industry. Strategic Management Journal. 15: 387-394.

Simonton D.K., 1999. Origins of genius. New York: Oxford University Press.

Smith S.W., Shah S.K., 2013. Do Innovative Users Generate More Useful Insights? An Analysis of Corporate Venture Capital Investments in the Medical Device industry. Strategic Entrepreneurship Journal. 7: 151-167.

Sorensen J.B., Stuart T.E., 2000. Aging, obsolescence, and organizational innovation. Administrative Science Quarterly. 45: $81-112$.

Srivastava M.K., Gnyawali D.R., 2011. When Do Relational Resources Matter? Leveraging Portfolio Technological

Resources for Breakthrough Innovation. Academy of Management Journal. 54: 797-810.

Stinchcombe A.L., 1965. Social Structure and Organizations. In: March J.G. editor editors. Handbook of Organizations. Chicago: Rand-McNally. p. 142-193.

Stirling A., 2007. A general framework for analysing diversity in science, technology and society. Journal of the Royal Society Interface. 4: 707-719.

Stuart T., Podolny J., 1996. Local search and the evolution of technological capabilities. Strategic Management Journal. 17: 21-38.

Stuart T.E., 1998. Network positions and propensities to collaborate: An investigation of strategic alliance formation in a high-technology industry. Administrative Science Quarterly. 43: 668.

Stuart T.E., 2000. Interorganizational alliances and the performance of firms: A study of growth and innovation rates in a high-technology industry. Strategic Management Journal. 21: 791-811.

Stuart T.E., Hoang H., Hybels R.C., 1999. Interorganizational endorsements and the performance of entrepreneurial ventures. Administrative Science Quarterly. 44: 315-349.

Tallman S., Phene A., 2007. Leveraging knowledge across geographic boundaries. Organization Science. 18: 252-260.

Teece D.J., Pisano G., Shuen A., 1997. Dynamic Capabilities and Strategic Management. Strategic Management Journal. 18: 509-533.

Trajtenberg M., 1987. Patents, citations, and innovations: Tracing the links. Working paper no. 2457. National Bureau of Economic Research. Washington, D.C.

Trajtenberg M., 1990. A penny for your quotes: Patent citations and the value of innovations. Rand Journal of Economics. 21: $172-187$.

Van de Vrande V., 2013. Balancing your technology-sourcing portfolio: How sourcing mode diversity enhances innovative performance. Strategic Management Journal. 34: 509-633.

van de Vrande V., Vanhaverbeke W., Duysters G., 2009. External technology sourcing: The effect of uncertainty on governance mode choice. Journal of Business Venturing. 24: 62-80.

Vassolo R.S., Anand J., Folta T.B., 2004. Portfolio effect in real options: The case of equity alliances in biotechnology. Strategic Management Journal. 25: 1045- 1061.

Vasudeva G., Anand J., 2011. Unpacking Absorptive Capacity: A Study of Knowledge Utilization from Alliance Portfolios. Academy of Management Journal. 54: 611-623.

von Hayek F., 1945. The use of knowledge in society. Technological opportunity and spillovers from R\&D: Evidence from firms' patents, profits and market value. xxxv: 519-530.

Wadhwa A., Kotha S.B., 2006. Knowledge creation through external venturing: Evidence from the telecommunications equipment manufacturing industry. Academy of Management Journal. 49: 819-835

Wassmer U., 2010. Alliance Portfolios: A Review and Research Agenda. Journal of Management. 36: 141-171 
Weitzman M., 1998. Recombinant growth. Quarterly Journal of Economics. 113: 331-360.

West J., Bogers M., 2014. Leveraging External Sources of Innovation: A Review of Research on Open Innovation. Journal of Product Innovation Management. 31: 814-831.

Wuyts S., Dutta S., 2012. Benefiting from Alliance Portfolio Diversity: The Role of Past Internal Knowledge Creation Strategy. Journal of Management.

Wuyts S., Dutta S., Stremersch S., 2004. Portfolios of Interfirm Agreements in Technology-Intensive Markets: Consequences for Innovation and Profitability. J Marketing. 68: 88-100.

Yang H., Phelps C., Steensma H.K., 2010. Learning from What Others Have Learned from You: The Effects of Knowledge Spillovers on Originating Firms. Academy of Management Journal. 53: 371-389.

Yang Y., Narayanan V.K., De Carolis D.M., 2013. The relationship between portfolio diversification and firm value: The evidence from corporate venture capital activity. Strategic Management Journal. n/a-n/a.

Zhao Z.J., Anand J., 2009. A multilevel perspective on knowledge transfer: evidence from the Chinese automotive industry. Strategic Management Journal. 30: 959-983.

Ziedonis A., 2007. Real options in technology licensing. Management Science. 53: 157-172.

Zollo M., Winter S.G., 2002. Deliberate learning and the evolution of dynamic capabilities. Organization Science. 13: 339351. 
Table 1: Descriptive statistics and correlations $(\mathrm{N}=417)$

\begin{tabular}{|c|c|c|c|c|c|c|c|c|c|c|c|c|c|c|c|c|c|c|c|}
\hline & & Mean & S.D. & Min & Max & (1) & $(2)$ & (3) & $(4)$ & $(5)$ & (6) & $(7)$ & $(8)$ & $(9)$ & $(10)$ & $(11)$ & $(12)$ & $(13)$ & $(14)$ \\
\hline & Innovation Performance & 2239.95 & 3259.56 & 0.00 & 23812.00 & 1 & & & & & & & & & & & & & \\
\hline (2) & Portfolio Diversity, t-1 & 0.23 & 0.41 & 0.00 & 1.89 & 0.048 & 1 & & & & & & & & & & & & \\
\hline (3) & Portfolio Depth, t-1 & 1.47 & 4.96 & 0.00 & 48.00 & 0.122 & 0.086 & 1 & & & & & & & & & & & \\
\hline (4) & Portfolio Partners, t-1 & 0.48 & 1.41 & 0.00 & 16.00 & 0.058 & 0.244 & 0.128 & 1 & & & & & & & & & & \\
\hline (5) & Investor Patent Count, $\mathrm{t}-1$ & 384.90 & 502.51 & 0.00 & 2516.00 & 0.758 & 0.133 & 0.117 & 0.063 & 1 & & & & & & & & & \\
\hline & Investor Sales, $\mathrm{t}-1$ & 8.34 & 2.37 & 0.48 & 11.49 & 0.481 & 0.216 & 0.146 & 0.184 & 0.61 & 1 & & & & & & & & \\
\hline & R\&D Intensity, $t-1$ & 0.10 & 0.20 & 0.00 & 3.30 & -0.091 & -0.043 & -0.015 & -0.042 & -0.102 & -0.388 & 1 & & & & & & & \\
\hline & Investor Current Ratio, $\mathrm{t}-1$ & 2.34 & 2.26 & 0.39 & 24.17 & -0.279 & -0.174 & -0.086 & -0.098 & -0.302 & -0.642 & 0.27 & 1 & & & & & & \\
\hline & Investor Age, $\mathrm{t}-1$ & 50.22 & 38.30 & 2.00 & 153.00 & 0.305 & 0.127 & -0.015 & 0.091 & 0.515 & 0.58 & -0.156 & -0.319 & 1 & & & & & \\
\hline (10) & Investor M\&A, t-1 & 7.50 & 10.25 & 0.00 & 62.50 & 0.24 & 0.158 & 0.073 & 0.13 & 0.427 & 0.419 & -0.078 & -0.199 & 0.56 & 1 & & & & \\
\hline & Investor JV \& Alliances, t-1 & 33.60 & 38.52 & 0.00 & 230.75 & 0.657 & 0.15 & 0.146 & 0.124 & 0.711 & 0.603 & -0.106 & -0.277 & 0.536 & 0.574 & 1 & & & \\
\hline (12) & Investor Tech Diversity, t-1 & 0.84 & 0.25 & 0.00 & 1.00 & 0.318 & 0.136 & 0.115 & 0.108 & 0.368 & 0.598 & -0.205 & -0.399 & 0.461 & 0.286 & 0.324 & 1 & & \\
\hline & Portfolio Size, t-1 & 2.17 & 5.60 & 0.00 & 54.00 & -0.015 & 0.791 & 0.061 & 0.145 & 0.06 & 0.169 & -0.016 & -0.107 & 0.083 & 0.179 & 0.117 & 0.073 & 1 & \\
\hline (14) & Investor CVC Experience, $\mathrm{t}-1$ & 2.09 & 1.72 & 0.00 & 5.48 & -0.074 & 0.398 & 0.208 & 0.125 & 0.072 & 0.25 & -0.091 & -0.14 & 0.2 & 0.236 & 0.103 & 0.29 & 0.329 & 1 \\
\hline
\end{tabular}


Table 2: Fixed effects negative binomial panel regression

Dependent variable $=$ Innovation Performance

\begin{tabular}{|c|c|c|c|c|c|c|c|}
\hline Variables & Model 1 & Model 2 & Model 3 & Model 4 & Model 5 & Model 6 & Model 7 \\
\hline Constant & $\begin{array}{l}-3.884 * * * \\
{[0.419]}\end{array}$ & $\begin{array}{l}-3.889 * * * \\
{[0.420]}\end{array}$ & $\begin{array}{l}-3.809 * * * \\
{[0.420]}\end{array}$ & $\begin{array}{l}-3.951 * * * \\
{[0.432]}\end{array}$ & $\begin{array}{l}-4.008^{* * *} \\
{[0.429]}\end{array}$ & $\begin{array}{l}-4.073 * * * \\
{[0.435]}\end{array}$ & $\begin{array}{l}-4.123 * * * \\
{[0.431]}\end{array}$ \\
\hline Portfolio Diversity, t-1 & & $\begin{array}{l}0.025 \\
{[0.101]}\end{array}$ & $\begin{array}{l}0.388^{*} \\
{[0.177]}\end{array}$ & $\begin{array}{l}0.423^{*} \\
{[0.184]}\end{array}$ & $\begin{array}{l}0.693^{* * *} \\
{[0.202]}\end{array}$ & $\begin{array}{l}0.798^{* * *} \\
{[0.233]}\end{array}$ & $\begin{array}{l}1.048^{* * *} \\
{[0.244]}\end{array}$ \\
\hline Portfolio Diversity Squared, t-1 & & & $\begin{array}{l}-0.534^{* *} \\
{[0.216]}\end{array}$ & $\begin{array}{l}-0.548^{* *} \\
{[0.227]}\end{array}$ & $\begin{array}{l}-0.862^{* * *} \\
{[0.254]}\end{array}$ & $\begin{array}{l}-1.003^{* * *} \\
{[0.281]}\end{array}$ & $\begin{array}{l}-1.286^{* * *} \\
{[0.299]}\end{array}$ \\
\hline Portfolio Depth, t-1 & & & & $\begin{array}{l}0.008^{*} \\
{[0.004]}\end{array}$ & $\begin{array}{l}0.011^{* *} \\
{[0.004]}\end{array}$ & $\begin{array}{l}0.009 * * \\
{[0.004]}\end{array}$ & $\begin{array}{l}0.011^{* *} \\
{[0.004]}\end{array}$ \\
\hline Portfolio Partners, t-1 & & & & $\begin{array}{l}-0.017 \\
{[0.014]}\end{array}$ & $\begin{array}{l}-0.022^{*} \\
{[0.013]}\end{array}$ & $\begin{array}{l}-0.012 \\
{[0.017]}\end{array}$ & $\begin{array}{l}-0.014 \\
{[0.017]}\end{array}$ \\
\hline Port. Diversity X Port. Depth & & & & & $\begin{array}{l}-0.101 * * \\
{[0.032]}\end{array}$ & & $\begin{array}{l}-0.096^{* *} \\
{[0.032]}\end{array}$ \\
\hline Port. Diversity Sq. X Port. Depth & & & & & $\begin{array}{l}0.107^{* *} \\
{[0.038]}\end{array}$ & & $\begin{array}{l}0.102^{* *} \\
{[0.037]}\end{array}$ \\
\hline Port. Diversity X Port. Partners & & & & & & $\begin{array}{l}-0.337 * * \\
{[0.132]}\end{array}$ & $\begin{array}{l}-0.334^{* *} \\
{[0.132]}\end{array}$ \\
\hline Port. Diversity Sq. X Port. Partners & & & & & & $\begin{array}{l}0.467 * * \\
{[0.168]}\end{array}$ & $\begin{array}{l}0.450^{* *} \\
{[0.168]}\end{array}$ \\
\hline Investor Patent Count, t-1 & $\begin{array}{l}0.001 * * * \\
{[0.000]}\end{array}$ & $\begin{array}{l}0.001 * * * \\
{[0.000]}\end{array}$ & $\begin{array}{l}0.001 * * * \\
{[0.000]}\end{array}$ & $\begin{array}{l}0.001 * * * \\
{[0.000]}\end{array}$ & $\begin{array}{l}0.001 * * * \\
{[0.000]}\end{array}$ & $\begin{array}{l}0.001 * * * \\
{[0.000]}\end{array}$ & $\begin{array}{l}0.001 * * * \\
{[0.000]}\end{array}$ \\
\hline Investor Sales, t-1 & $\begin{array}{l}0.411 * * * \\
{[0.044]}\end{array}$ & $\begin{array}{l}0.412 * * * \\
{[0.044]}\end{array}$ & $\begin{array}{l}0.398^{* * * *} \\
{[0.044]}\end{array}$ & $\begin{array}{l}0.421 * * * \\
{[0.046]}\end{array}$ & $\begin{array}{l}0.420^{* * *} \\
{[0.045]}\end{array}$ & $\begin{array}{l}0.437 * * * \\
{[0.046]}\end{array}$ & $\begin{array}{l}0.437 * * * \\
{[0.045]}\end{array}$ \\
\hline $\mathrm{R} \& \mathrm{D}$ Intensity, $\mathrm{t}-1$ & $\begin{array}{l}0.943^{* *} \\
{[0.348]}\end{array}$ & $\begin{array}{l}0.940 * * \\
{[0.349]}\end{array}$ & $\begin{array}{l}0.896^{*} \\
{[0.349]}\end{array}$ & $\begin{array}{l}0.965^{* *} \\
{[0.349]}\end{array}$ & $\begin{array}{l}0.938^{* *} \\
{[0.353]}\end{array}$ & $\begin{array}{l}1.012 * * \\
{[0.350]}\end{array}$ & $\begin{array}{l}0.994 * * \\
{[0.352]}\end{array}$ \\
\hline Investor Current Ratio, t-1 & $\begin{array}{l}-0.030 \\
{[0.028]}\end{array}$ & $\begin{array}{l}-0.030 \\
{[0.028]}\end{array}$ & $\begin{array}{l}-0.032 \\
{[0.028]}\end{array}$ & $\begin{array}{l}-0.033 \\
{[0.029]}\end{array}$ & $\begin{array}{l}-0.025 \\
{[0.028]}\end{array}$ & $\begin{array}{l}-0.031 \\
{[0.028]}\end{array}$ & $\begin{array}{l}-0.023 \\
{[0.027]}\end{array}$ \\
\hline Investor Age, t-1 & $\begin{array}{l}0.003 \\
{[0.002]}\end{array}$ & $\begin{array}{l}0.003 \\
{[0.002]}\end{array}$ & $\begin{array}{l}0.004+ \\
{[0.002]}\end{array}$ & $\begin{array}{l}0.003 \\
{[0.002]}\end{array}$ & $\begin{array}{l}0.004 * \\
{[0.002]}\end{array}$ & $\begin{array}{l}0.004+ \\
{[0.002]}\end{array}$ & $\begin{array}{l}0.005^{*} \\
{[0.002]}\end{array}$ \\
\hline Investor M\&A, t-1 & $\begin{array}{l}0.008^{* *} \\
{[0.003]}\end{array}$ & $\begin{array}{l}0.008^{* *} \\
{[0.003]}\end{array}$ & $\begin{array}{l}0.008^{* *} \\
{[0.003]}\end{array}$ & $\begin{array}{l}0.009 * * \\
{[0.003]}\end{array}$ & $\begin{array}{l}0.009 * * * \\
{[0.003]}\end{array}$ & $\begin{array}{l}0.009 * * \\
{[0.003]}\end{array}$ & $\begin{array}{l}0.009 * * * \\
{[0.003]}\end{array}$ \\
\hline Investor JV \& Alliances, t-1 & $\begin{array}{l}0.001 \\
{[0.001]}\end{array}$ & $\begin{array}{l}0.001 \\
{[0.001]}\end{array}$ & $\begin{array}{l}0.001 \\
{[0.001]}\end{array}$ & $\begin{array}{l}0.000 \\
{[0.001]}\end{array}$ & $\begin{array}{l}0.000 \\
{[0.001]}\end{array}$ & $\begin{array}{l}-0.000 \\
{[0.001]}\end{array}$ & $\begin{array}{l}-0.000 \\
{[0.001]}\end{array}$ \\
\hline Investor Tech Diversity, t-1 & $\begin{array}{l}1.620 * * * \\
{[0.360]}\end{array}$ & $\begin{array}{l}1.623 * * * \\
{[0.360]}\end{array}$ & $\begin{array}{l}1.607 * * * \\
{[0.357]}\end{array}$ & $\begin{array}{l}1.618^{* * * *} \\
{[0.360]}\end{array}$ & $\begin{array}{l}1.605^{* * * *} \\
{[0.361]}\end{array}$ & $\begin{array}{l}1.610^{* * * *} \\
{[0.363]}\end{array}$ & $\begin{array}{l}1.584 * * * \\
{[0.363]}\end{array}$ \\
\hline Portfolio Size, t-1 & $\begin{array}{l}-0.030^{* * *} \\
{[0.005]}\end{array}$ & $\begin{array}{l}-0.032^{* * *} \\
{[0.008]}\end{array}$ & $\begin{array}{l}-0.001 \\
{[0.014]}\end{array}$ & $\begin{array}{l}-0.003 \\
{[0.014]}\end{array}$ & $\begin{array}{l}-0.001 \\
{[0.014]}\end{array}$ & $\begin{array}{l}-0.008 \\
{[0.014]}\end{array}$ & $\begin{array}{l}-0.007 \\
{[0.014]}\end{array}$ \\
\hline Investor CVC Experience, $\mathrm{t}-1$ & $\begin{array}{l}-0.055 \\
{[0.036]}\end{array}$ & $\begin{array}{l}-0.058 \\
{[0.038]}\end{array}$ & $\begin{array}{l}-0.058 \\
{[0.038]}\end{array}$ & $\begin{array}{l}-0.065+ \\
{[0.039]}\end{array}$ & $\begin{array}{l}-0.046 \\
{[0.041]}\end{array}$ & $\begin{array}{l}-0.075+ \\
{[0.039]}\end{array}$ & $\begin{array}{l}-0.058 \\
{[0.040]}\end{array}$ \\
\hline $\begin{array}{l}\text { Firm Dummies } \\
\text { Time Dummies }\end{array}$ & $\begin{array}{l}\text { Fixed } \\
\text { Yes }\end{array}$ & $\begin{array}{l}\text { Fixed } \\
\text { Yes }\end{array}$ & $\begin{array}{l}\text { Fixed } \\
\text { Yes }\end{array}$ & $\begin{array}{l}\text { Fixed } \\
\text { Yes }\end{array}$ & $\begin{array}{l}\text { Fixed } \\
\text { Yes }\end{array}$ & $\begin{array}{l}\text { Fixed } \\
\text { Yes }\end{array}$ & $\begin{array}{l}\text { Fixed } \\
\text { Yes }\end{array}$ \\
\hline Observations & 417 & 417 & 417 & 417 & 417 & 417 & 417 \\
\hline Degrees of Freedom & 20 & 21 & 22 & 24 & 26 & 26 & 28 \\
\hline Log Likelihood & -2509.857 & -2509.826 & -2506.781 & -2504.013 & -2498.711 & -2499.964 & -2495.015 \\
\hline $\begin{array}{l}-2 \text { Log Likelihood } \\
\text { Wald Chi } 2\end{array}$ & 941.952 & $\begin{array}{l}0.062 \\
939.662\end{array}$ & $\begin{array}{l}6.152 \\
962.555\end{array}$ & $\begin{array}{l}11.688 \\
967.102\end{array}$ & $\begin{array}{l}22.292 \\
992.723\end{array}$ & $\begin{array}{l}19.786 \\
987.105\end{array}$ & $\begin{array}{l}29.684 \\
1013.496\end{array}$ \\
\hline
\end{tabular}

Standard errors in brackets

*** $\mathrm{p}<0.001,{ }^{* *} \mathrm{p}<0.01, * \mathrm{p}<0.05,+\mathrm{p}<0.1$

Two-tailed tests for control variables and one-tailed tests for hypothesized variables 
Table 3: Fixed effects negative binomial panel regression with restricted sample ${ }^{3}$ Dependent variable $=$ Innovation Performance

\begin{tabular}{|c|c|c|c|c|c|c|c|}
\hline Variables & Model 1 & Model 2 & Model 3 & Model 4 & Model 5 & Model 6 & Model 7 \\
\hline Constant & $\begin{array}{c}-2.722 * * * \\
{[0.748]}\end{array}$ & $\begin{array}{c}-2.763^{* * *} \\
{[0.757]}\end{array}$ & $\begin{array}{c}-2.456^{* *} \\
{[0.751]}\end{array}$ & $\begin{array}{c}-2.809 * * * \\
{[0.790]}\end{array}$ & $\begin{array}{c}-2.791 * * * \\
{[0.797]}\end{array}$ & $\begin{array}{c}-2.994 * * * \\
{[0.808]}\end{array}$ & $\begin{array}{c}-3.000 * * * \\
{[0.815]}\end{array}$ \\
\hline Portfolio Diversity, t-1 & & $\begin{array}{c}0.042 \\
{[0.109]}\end{array}$ & $\begin{array}{c}0.479 * \\
{[0.229]}\end{array}$ & $\begin{array}{l}0.505^{*} \\
{[0.227]}\end{array}$ & $\begin{array}{c}0.726^{* *} \\
{[0.265]}\end{array}$ & $\begin{array}{c}0.772^{* *} \\
{[0.273]}\end{array}$ & $\begin{array}{c}1.006^{* * *} \\
{[0.304]}\end{array}$ \\
\hline Portfolio Diversity Squared, t-1 & & & $\begin{array}{c}-0.545^{*} \\
{[0.247]}\end{array}$ & $\begin{array}{l}-0.521 * \\
{[0.245]}\end{array}$ & $\begin{array}{c}-0.872^{* *} \\
{[0.299]}\end{array}$ & $\begin{array}{c}-0.833^{* *} \\
{[0.299]}\end{array}$ & $\begin{array}{c}-1.201 * * * \\
{[0.344]}\end{array}$ \\
\hline Portfolio Depth, t-1 & & & & $\begin{array}{l}0.010^{*} \\
{[0.004]}\end{array}$ & $\begin{array}{c}0.011 * * \\
{[0.004]}\end{array}$ & $\begin{array}{c}0.010^{* *} \\
{[0.004]}\end{array}$ & $\begin{array}{c}0.011 * * \\
{[0.004]}\end{array}$ \\
\hline Portfolio Partners, t-1 & & & & $\begin{array}{l}-0.009 \\
{[0.014]}\end{array}$ & $\begin{array}{l}-0.015 \\
{[0.015]}\end{array}$ & $\begin{array}{l}-0.011 \\
{[0.021]}\end{array}$ & $\begin{array}{l}-0.009 \\
{[0.020]}\end{array}$ \\
\hline Port. Diversity X Port. Depth & & & & & $\begin{array}{l}-0.065^{*} \\
{[0.031]}\end{array}$ & & $\begin{array}{c}-0.063 * \\
{[0.031]}\end{array}$ \\
\hline Port. Diversity Sq. X Port. Depth & & & & & $\begin{array}{l}0.082 * \\
{[0.036]}\end{array}$ & & $\begin{array}{l}0.082^{* *} \\
{[0.035]}\end{array}$ \\
\hline Port. Diversity X Port. Partners & & & & & & $\begin{array}{c}-0.209+ \\
{[0.131]}\end{array}$ & $\begin{array}{l}-0.248^{*} \\
{[0.134]}\end{array}$ \\
\hline Port. Diversity Sq. X Port. Partners & & & & & & $\begin{array}{c}0.294^{*} \\
{[0.159]}\end{array}$ & $\begin{array}{c}0.321 * * \\
{[0.164]}\end{array}$ \\
\hline Investor Patent Count, t-1 & $\begin{array}{c}0.001 * * * \\
{[0.000]}\end{array}$ & $\begin{array}{c}0.001^{* * *} \\
{[0.000]}\end{array}$ & $\begin{array}{c}0.001^{* * *} \\
{[0.000]}\end{array}$ & $\begin{array}{c}0.001 * * * \\
{[0.000]}\end{array}$ & $\begin{array}{c}0.001^{* * *} \\
{[0.000]}\end{array}$ & $\begin{array}{c}0.001^{* * *} \\
{[0.000]}\end{array}$ & $\begin{array}{c}0.001 * * * \\
{[0.000]}\end{array}$ \\
\hline Investor Sales, t-1 & $\begin{array}{c}0.202 * \\
{[0.092]}\end{array}$ & $\begin{array}{l}0.206^{*} \\
{[0.092]}\end{array}$ & $\begin{array}{c}0.155 \\
{[0.096]}\end{array}$ & $\begin{array}{c}0.217^{*} \\
{[0.100]}\end{array}$ & $\begin{array}{c}0.207^{*} \\
{[0.102]}\end{array}$ & $\begin{array}{l}0.243^{*} \\
{[0.100]}\end{array}$ & $\begin{array}{l}0.237^{*} \\
{[0.102]}\end{array}$ \\
\hline R\&D Intensity, t-1 & $\begin{array}{l}-0.259 \\
{[0.543]}\end{array}$ & $\begin{array}{l}-0.263 \\
{[0.549]}\end{array}$ & $\begin{array}{l}-0.353 \\
{[0.527]}\end{array}$ & $\begin{array}{l}-0.180 \\
{[0.554]}\end{array}$ & $\begin{array}{l}-0.198 \\
{[0.543]}\end{array}$ & $\begin{array}{l}-0.104 \\
{[0.567]}\end{array}$ & $\begin{array}{l}-0.106 \\
{[0.553]}\end{array}$ \\
\hline Investor Current Ratio, $\mathrm{t}-1$ & $\begin{array}{c}0.043 \\
{[0.036]}\end{array}$ & $\begin{array}{c}0.045 \\
{[0.036]}\end{array}$ & $\begin{array}{c}0.036 \\
{[0.035]}\end{array}$ & $\begin{array}{c}0.044 \\
{[0.037]}\end{array}$ & $\begin{array}{c}0.041 \\
{[0.036]}\end{array}$ & $\begin{array}{c}0.048 \\
{[0.037]}\end{array}$ & $\begin{array}{c}0.045 \\
{[0.036]}\end{array}$ \\
\hline Investor Age, t-1 & $\begin{array}{l}0.006+ \\
{[0.003]}\end{array}$ & $\begin{array}{l}0.006+ \\
{[0.003]}\end{array}$ & $\begin{array}{c}0.008^{*} \\
{[0.003]}\end{array}$ & $\begin{array}{l}0.007^{*} \\
{[0.003]}\end{array}$ & $\begin{array}{l}0.008^{*} \\
{[0.003]}\end{array}$ & $\begin{array}{l}0.008^{*} \\
{[0.003]}\end{array}$ & $\begin{array}{c}0.009 * * \\
{[0.004]}\end{array}$ \\
\hline Investor M\&A, t-1 & $\begin{array}{c}0.018^{* * *} \\
{[0.004]}\end{array}$ & $\begin{array}{c}0.018^{* * *} \\
{[0.004]}\end{array}$ & $\begin{array}{c}0.017 * * * \\
{[0.004]}\end{array}$ & $\begin{array}{c}0.019^{* * *} \\
{[0.004]}\end{array}$ & $\begin{array}{c}0.020 * * * \\
{[0.004]}\end{array}$ & $\begin{array}{c}0.019^{* * *} \\
{[0.004]}\end{array}$ & $\begin{array}{c}0.021 * * * \\
{[0.004]}\end{array}$ \\
\hline Investor JV \& Alliances, t-1 & $\begin{array}{c}0.002 \\
{[0.001]}\end{array}$ & $\begin{array}{c}0.002 \\
{[0.001]}\end{array}$ & $\begin{array}{c}0.002 \\
{[0.001]}\end{array}$ & $\begin{array}{c}0.001 \\
{[0.001]}\end{array}$ & $\begin{array}{c}0.001 \\
{[0.001]}\end{array}$ & $\begin{array}{c}0.001 \\
{[0.001]}\end{array}$ & $\begin{array}{c}0.000 \\
{[0.001]}\end{array}$ \\
\hline Investor Tech Diversity, t-1 & $\begin{array}{c}2.565^{* * *} \\
{[0.704]}\end{array}$ & $\begin{array}{c}2.575^{* * *} \\
{[0.707]}\end{array}$ & $\begin{array}{c}2.528^{* * *} \\
{[0.699]}\end{array}$ & $\begin{array}{c}2.342^{* * *} \\
{[0.704]}\end{array}$ & $\begin{array}{c}2.271 * * \\
{[0.695]}\end{array}$ & $\begin{array}{c}2.360 * * * \\
{[0.705]}\end{array}$ & $\begin{array}{c}2.281 * * \\
{[0.697]}\end{array}$ \\
\hline Portfolio Size, t-1 & $\begin{array}{c}-0.021 * * * \\
{[0.006]}\end{array}$ & $\begin{array}{c}-0.023^{* *} \\
{[0.008]}\end{array}$ & $\begin{array}{c}0.006 \\
{[0.015]}\end{array}$ & $\begin{array}{c}0.001 \\
{[0.015]}\end{array}$ & $\begin{array}{c}0.007 \\
{[0.015]}\end{array}$ & $\begin{array}{l}-0.001 \\
{[0.015]}\end{array}$ & $\begin{array}{c}0.003 \\
{[0.015]}\end{array}$ \\
\hline Investor CVC Experience, $\mathrm{t}-1$ & $\begin{array}{c}-0.112+ \\
{[0.058]}\end{array}$ & $\begin{array}{r}-0.119+ \\
{[0.062]}\end{array}$ & $\begin{array}{r}-0.111+ \\
{[0.063]}\end{array}$ & $\begin{array}{l}-0.102 \\
{[0.066]}\end{array}$ & $\begin{array}{l}-0.033 \\
{[0.074]}\end{array}$ & $\begin{array}{c}-0.125+ \\
{[0.067]}\end{array}$ & $\begin{array}{l}-0.060 \\
{[0.073]}\end{array}$ \\
\hline $\begin{array}{l}\text { Firm Dummies } \\
\text { Time Dummies }\end{array}$ & $\begin{array}{l}\text { Fixed } \\
\text { Yes }\end{array}$ & $\begin{array}{l}\text { Fixed } \\
\text { Yes }\end{array}$ & $\begin{array}{l}\text { Fixed } \\
\text { Yes }\end{array}$ & $\begin{array}{l}\text { Fixed } \\
\text { Yes }\end{array}$ & $\begin{array}{l}\text { Fixed } \\
\text { Yes }\end{array}$ & $\begin{array}{l}\text { Fixed } \\
\text { Yes }\end{array}$ & $\begin{array}{l}\text { Fixed } \\
\text { Yes }\end{array}$ \\
\hline Observations & 209 & 209 & 209 & 209 & 209 & 209 & 209 \\
\hline Degrees of Freedom & 20.000 & 21.000 & 22.000 & 24.000 & 26.000 & 26.000 & 28.000 \\
\hline Log Likelihood & -1193.213 & -1193.139 & -1190.738 & -1188.474 & -1185.843 & -1186.616 & -1183.941 \\
\hline-2 Log Likelihood & & 0.148 & 4.95 & 9.478 & 14.74 & 13.194 & 18.544 \\
\hline Wald Chi 2 & 459.260 & 456.019 & 487.918 & 507.602 & 506.218 & 522.083 & 518.383 \\
\hline
\end{tabular}

Standard errors in brackets; *** $\mathrm{p}<0.001, * * \mathrm{p}<0.01, * \mathrm{p}<0.05,+\mathrm{p}<0.1$

Two-tailed tests for control variables and one-tailed tests for hypothesized variables

${ }^{3}$ The restricted sample consists of those observations where the size of the investor's portfolio is greater than zero. 
Figure 1: Portfolio Depth (Patents) as moderator of Portfolio Diversity
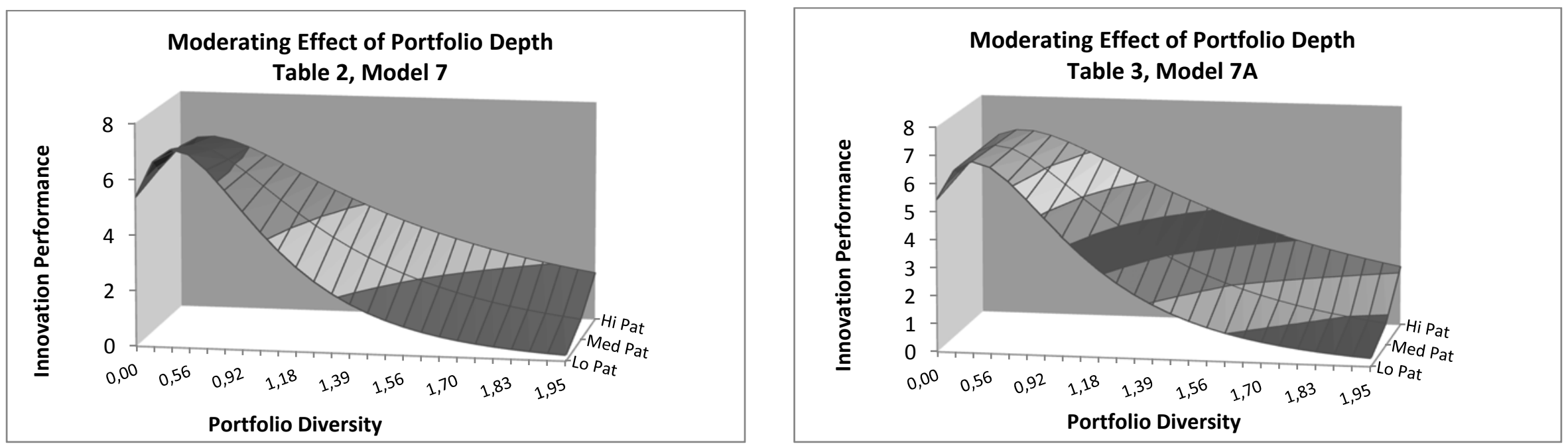

Figure 2: Portfolio Partners as moderator of Portfolio Diversity
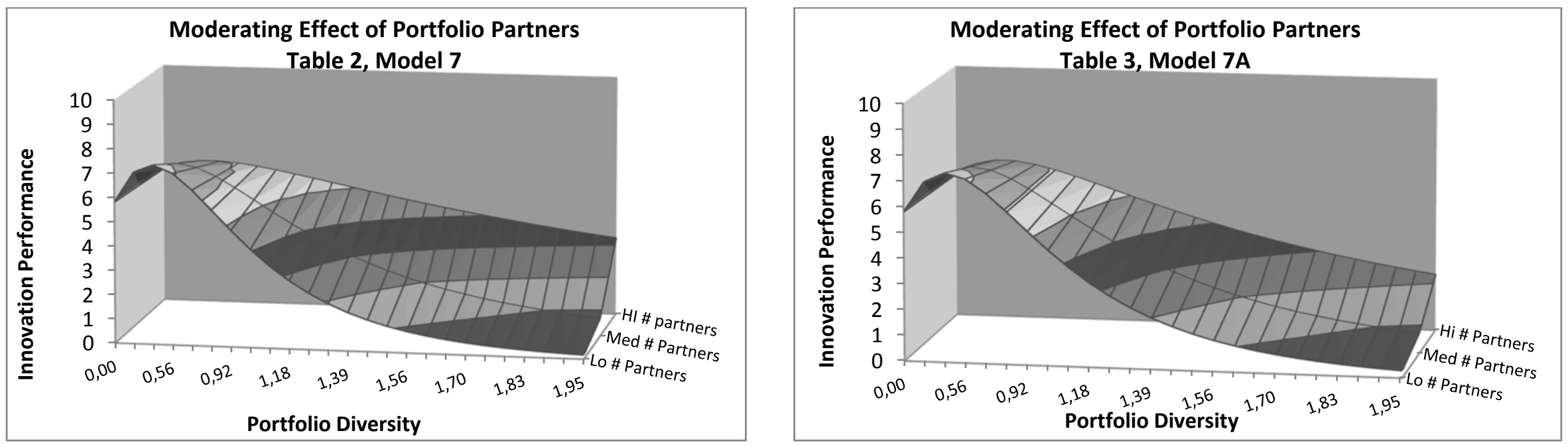